\title{
The impact of RASopathy-associated mutations on CNS development in mice and humans
}

\author{
Minkyung Kang ${ }^{1,2}$ and Yong-Seok Lee ${ }^{1,2,3^{*}}$ (D)
}

\begin{abstract}
The RAS signaling pathway is involved in the regulation of developmental processes, including cell growth, proliferation, and differentiation, in the central nervous system (CNS). Germline mutations in the RAS signaling pathway genes are associated with a group of neurodevelopmental disorders, collectively called RASopathy, which includes neurofibromatosis type 1, Noonan syndrome, cardio-facio-cutaneous syndrome, and Costello syndrome. Most mutations associated with RASopathies increase the activity of the RAS-ERK signaling pathway, and therefore, most individuals with RASopathies share common phenotypes, such as a short stature, heart defects, facial abnormalities, and cognitive impairments, which are often accompanied by abnormal CNS development. Recent studies using mouse models of RASopathies demonstrated that particular mutations associated with each disorder disrupt CNS development in a mutation-specific manner. Here, we reviewed the recent literatures that investigated the developmental role of RASopathy-associated mutations using mutant mice, which provided insights into the specific contribution of RAS-ERK signaling molecules to CNS development and the subsequent impact on cognitive function in adult mice.
\end{abstract}

Keywords: RAS, MAPK, neurodevelopmental disorders, cognition, mutant strains mouse

\section{Introduction}

The RAS-extracellular signal-regulated kinase (ERK) pathway is a highly conserved signaling cascade that transduces signals from membrane receptors to the cytoplasm and nucleus by protein-protein interactions and phosphorylation [1-3]. It plays a critical role in controlling various cellular processes, including cell growth, survival, proliferation, and differentiation, in developing and adult tissues, such as the brain [2, 4]. RAS, which is composed of a multigene family that includes $H R A S$, $K R A S$, and NRAS, encodes a small guanosine nucleotidebound GTPase protein, and the activation of the RASERK signal transduction is initiated by the binding of growth factors to G-protein-coupled receptors, such as receptor tyrosine kinases (RTKs) and cytokine receptors. $R A S$ is activated by guanine nucleotide exchange factors

\footnotetext{
* Correspondence: yongseok7@snu.ac.kr

'Department of Physiology, Seoul National University College of Medicine, 103 Daehak-ro, Jongro-gu, Seoul 03080, South Korea

${ }^{2}$ Department of Biomedical Sciences, Seoul National University College of Medicine, Seoul 03080, Korea

Full list of author information is available at the end of the article
}

(GEFs), such as SOS1, whose activity is regulated by multiple adaptor proteins, including GAB1 and GRB2 (Fig. 1) [5]. On the contrary, GTPase activating proteins (GAPs), such as NF1, switch RAS activity off by hydrolyzing GTP to GDP. The GTP-bound form of active RAS leads to the activation of its direct downstream effector, RAF. RAF encodes a serine/threonine kinase and represents the RAF family, which also includes ARAF, BRAF, and RAF1. RAF phosphorylates and activates the MAPK kinase, MAPK/ERK kinase 1/2 (MEK1/2), which in turn activates ERK1 and ERK2 by phosphorylating the tyrosine and threonine residues on ERK1/2 [6]. ERK1 and ERK2 are homologous subtypes of the ERK family and are final effectors of the RAS-ERK pathway. ERK1/2 affect a large number of downstream molecules, such as nuclear components, transcription factors, and membrane proteins [7].

Since the RAS-ERK pathway is critically involved in multiple biological processes, germline mutations in RAS-ERK signaling components can cause a class of developmental disorders that are collectively called RASopathy $[3,8,9]$. 


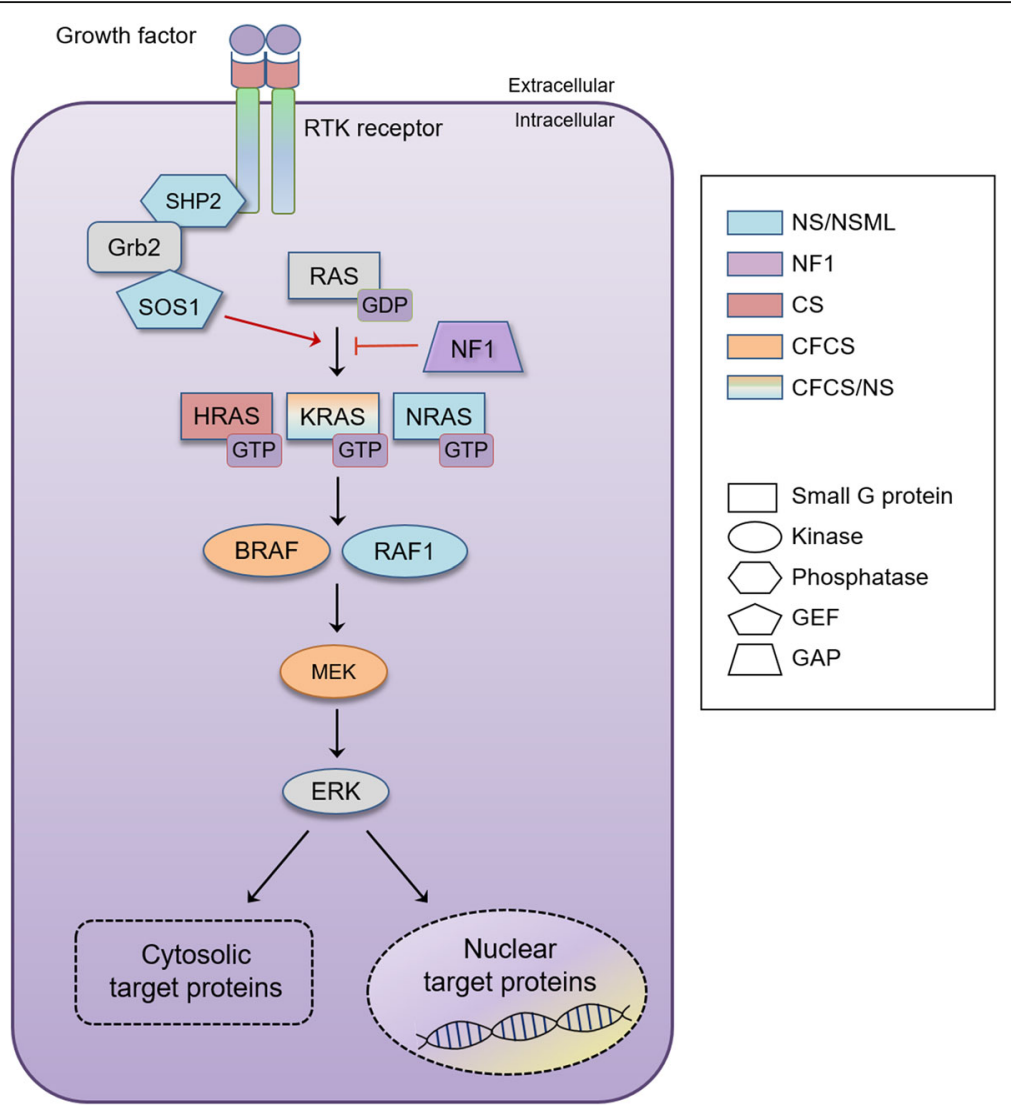

Fig. 1 The RAS-ERK signaling pathway and associated disorders. A simplified RAS-ERK signaling pathway. Genes frequently mutated in RASopathy are colored based on the RASopathy and are displayed as a polygon depending on their functional categories. NS/NSML, Noonan syndrome/ Noonan syndrome with multiple lentigines; NF1, Neurofibromatosis type 1; CS, Costello syndrome; CFCS, Cardio-facio-cutaneous syndrome; GEF, guanine exchange factor; GAP, GTPase activating protein.

RASopathy affects approximately 1 in 1,000 live births worldwide and shares a common molecular mechanism, such as mutations in RAS-ERK signaling components [4]. Representatively, RASopathy includes 1) neurofibromatosis type 1 , which is caused by loss of function mutations in $N F 1$; 2) Noonan syndrome, caused by gain of function mutations in PTPN11, SOS1, SHOC2, CBL, KRAS, NRAS, $B R A F, R A F 1$, and MEK1; 3) Noonan syndrome with multiple lentigines that is caused by mutations in PTPN11 and $R A F 1$; 4) cardio-facio-cutaneous syndrome, which is caused by either gain of function or loss of function mutations in $B R A F, K R A S, M E K 1$, and MEK2; 5) Costello syndrome, caused by gain of function mutations in HRAS; and 6) neurofibromatosis type 1-like syndrome (NFLS or Legius syndrome) that is also caused by loss of function mutations in NF1. RASopathies share typical characteristics, such as a short stature, craniofacial dysmorphism, cardiac defects, and neurocognitive impairments that are accompanied by abnormal brain development [10]. However, each RASopathy also displays distinct and unique symptoms, depending on the mutated genes $[3,11]$. Consistently, recent studies using mouse models of RASopathies have demonstrated that each disorder also shows disease-specific abnormalities in central nervous system (CNS) development. Here, we review the distinctive roles of RASERK signaling molecules in CNS development that were revealed by investigating the deficits in CNS development of RASopathies (Tables 1 and 2). Furthermore, we also review how RASopathy-associated mutations affect cognitive function in mice and human.

\section{RAS-ERK signaling and nervous system development}

The RAS-ERK signaling pathway is tightly regulated during CNS development and many studies have demonstrated that the dysregulation of this signaling pathway results in aberrant brain development. There are a number of studies demonstrating that ERK1/2, the final effectors of RAS-ERK signaling, are involved in cell proliferation and differentiation in the nervous system [110]. Activation of ERK signaling is required for neural stem cells (NSCs) to maintain their ability to self-renew and form neurospheres, indicating that ERK may act as a critical regulator in the maintenance of NSCs [111]. In addition, it has also been shown that ERK signaling 
Table 1 Human patients with RASopathies and their phenotypes

\begin{tabular}{|c|c|c|c|}
\hline Disease & Associated genes & CNS structural phenotypes & Other phenotypes \\
\hline Neurofibromatosis type 1 & NF1 (95\%) [12] & $\begin{array}{l}\text { Neurofibromas, abnormal cortical } \\
\text { development [13], abnormal glial } \\
\text { development [14], macrocephaly }\end{array}$ & $\begin{array}{l}\text { Below-average IQ, ADHD, impaired } \\
\text { executive functioning, deficits in } \\
\text { visual-spatial skills }[15,16] \text {, } \\
\text { hyperpigmentation of melanocytes, } \\
\text { hamartomas of the iris }[17,18] \text {, bone } \\
\text { malformation, cardiac defects }[19,20\end{array}$ \\
\hline $\begin{array}{l}\text { Noonan syndrome, } \\
\text { Noonan syndrome with } \\
\text { multiple lentigines }\end{array}$ & $\begin{array}{l}\text { PTPN11 (>50\%) [21], RAF1 } \\
(3-17 \%)[22,23], \text { SOS1 } \\
(9-13 \%)[24] \text { KRAS }(<2 \%) \\
{[25,26], \text { BRAF }(<2 \%)[22]} \\
\text { MEK1/2 (<2\%) [27] }\end{array}$ & $\begin{array}{l}\text { Cerebellar ectopia [28, 29], temporal } \\
\text { lobe anomaly, hydrocephalus, } \\
\text { cerebral abscess [30-32], epilepsy, } \\
\text { cortical dysplasia [33] }\end{array}$ & $\begin{array}{l}\text { Neurocognitive delay [33-35], typical } \\
\text { facial abnormalities, short stature, } \\
\text { motor delay, increased risk of } \\
\text { cancer, cardiac defects [34-40] }\end{array}$ \\
\hline $\begin{array}{l}\text { Cardio-facio-cutaneous } \\
\text { syndrome }\end{array}$ & $\begin{array}{l}\text { BRAF }(43-78 \%)[41-43] \\
\text { MEK1/2 (7-11\%) [42, 43], } \\
\text { KRAS (5-8\%) }[25,43]\end{array}$ & $\begin{array}{l}\text { Ventriculomegaly, hydrocephalus } \\
\text { [44-50], atrophy }[44,46,51-54] \text {, } \\
\text { migration and myelination } \\
\text { abnormalities, agenesis of } \\
\text { corpus callosum }[50,52,55-57]\end{array}$ & $\begin{array}{l}\text { Neurological abnormalities, seizures, } \\
\text { tactile defensiveness, learning } \\
\text { disabilities }[4,50,55] \text {, craniofacial } \\
\text { defects, cardiac defects }[4,58,59] \text {, } \\
\text { motor delay, hypotonia }[4,50,55]\end{array}$ \\
\hline Costello syndrome & $\begin{array}{l}\operatorname{HRAS}(85-90 \%)[60-62] \text {, } \\
\text { KRAS (7\%) [63], BRAF } \\
(4-6 \%)[27], \text { MEK1/2 } \\
(2-3 \%)[27]\end{array}$ & $\begin{array}{l}\text { Ventricular abnormalities }[64-67], \\
\text { cerebral malformations }[64,65,67-71] \text {, } \\
\text { cerebellar abnormalities }[66,69,71-74] \text {, } \\
\text { macrocephaly }[59,60]\end{array}$ & $\begin{array}{l}\text { Mental retardation }[59,60] \text {, facial } \\
\text { features, loose skin, severe failure } \\
\text { to thrive, predisposition to } \\
\text { tumors }[59,60]\end{array}$ \\
\hline
\end{tabular}

IQ Intelligence quotient, $A D H D$ Attention deficit hyperactivity disorder;

promotes neuronal survival by multiple mechanisms $[112,113]$. For example, an ERK-activated kinase, ribosomal S6 Kinase (RSK), phosphorylates the proapoptotic protein BAD and suppresses BAD-mediated apoptosis in neurons [112]. ERK was also shown to regulate the activation of anti-apoptotic regulators, such as Bcl-2, CREB, and STAT3/5, and subsequently promote cell survival $[112,114,115]$. However, in spite of the crucial role of ERK in neuronal survival, aberrant and long-lasting ERK activation has also been implicated in neurodegenerative diseases [116, 117].

Several studies have implied that the MEK/ERK signaling cascade has a crucial role in neurogenesis. ERK2 is necessary for regulating the proliferation of neurogenic precursors and the positive regulation of neurotrophininduced neurogenesis by the MEK-C/EBP pathway during cortical development $[118,119]$. Despite the evidence that MEK is required for neurogenesis, in vivo and in vitro studies have demonstrated that ERK also regulates and maintains the pool of glial populations in the developing brain [109]. NSC-specific ablation of Mek1/2 induces a complete blockade of glial specificity and gliogenesis failure, while Mek1 gain of function promotes precocious glial progenitor specification in mice [109]. Several studies have demonstrated that in vitro, Erk1 and Erk2 are critical components of proliferation in cultured rat astrocytes, and that MEK/ERK signaling induces gliogenic signals, such as SDF-1a and FGF2 [120-122]. Consistently, treatment with the MEK inhibitor PD98059 induced a reduction in astrocytic growth, suggesting that MEK/ERK signaling is involved in astrocyte proliferation [122]. In addition, the chemical inhibition of MEK also impairs the ability of oligodendrocyte precursors to differentiate into mature oligodendrocyte in vitro, suggesting that both oligodendrocytes and astrocytes are regulated by ERK signaling [103]. Several studies demonstrated that the pharmacological inhibition of ERK1/2 signaling in oligodendrocyte progenitors negatively regulates differentiation and the transition of early progenitors to late oligodendrocyte progenitors [123-125]. Furthermore, ERK signaling promotes oligodendrocyte myelination [126]. However, there are conflicting results about the role of ERK signaling in the differentiation of oligodendrocyte progenitors into mature oligodendrocytes. Recently, Suo and colleagues demonstrated that MEK inhibitors significantly enhance the differentiation of oligodendrocyte precursor cells into oligodendrocytes in vitro and in vivo [127]. Consistently, many studies have suggested that increased ERK activity negatively regulates oligodendrocyte differentiation. For example, ERK1/2 activation, which is induced by high dose stimulation of neuregulin-1 or fibroblast growth factor-2 in mature oligodendrocytes, results in downregulated myelin proteins and aberrant cell cycle re-entry [128-130].

The RAS-ERK signaling pathway also regulates the expression of transcription factors, such as cell fate determinants. Numerous studies demonstrated that the enhanced activity of RAS-ERK signaling induces the expression of the transcription factor $O L I G 2$, which promotes the fate of NSCs to the glial lineage [85, 90, 108]. Furthermore, the activation of RAS-ERK signaling promotes the expression of the pro-neural gene Achaete scute-like 1 (Ascl1) but blocks pro-neural gene Neurogenin 2 (Neurog2) expression. Neurog 2 specifies glutamatergic neuronal cell fate in dorsal progenitors, while Ascl1 specifies neocortical gamma-aminobutyric acidergic (GABAergic) neurons and 
Table 2 RASopathy mouse models and their phenotypes

\begin{tabular}{|c|c|c|c|}
\hline Gene & Mouse model & CNS structural phenotypes & Other phenotypes \\
\hline \multirow[t]{6}{*}{ Nf1 } & Nf1 homozygous knockout & $\begin{array}{l}\text { Defects in the neural tube, hyperplasia of } \\
\text { neural crest-derived ganglia [75] }\end{array}$ & $\begin{array}{l}\text { Embryonic lethality, heart defects, delay in } \\
\text { organ development }[76,77]\end{array}$ \\
\hline & Nf1 heterozygous knockout & Increased number of astrocytes $[78,79]$ & $\begin{array}{l}\text { Impaired synaptic plasticity, impaired spatial } \\
\text { learning, heart defects [80-82] }\end{array}$ \\
\hline & Synapsin 1-dependent Nf1 ablation & $\begin{array}{l}\text { Reduced size and weight of the forebrain, } \\
\text { reduced cortical thickness, increased } \\
\text { astrogliogenesis [83] }\end{array}$ & Learning deficits, growth retardation $[83,84]$ \\
\hline & hGFAP-dependent Nf1 ablation & $\begin{array}{l}\text { Increased gliogenesis, enlarged } \\
\text { cerebral cortex, defective GNP } \\
\text { migration and proliferation } \\
\text { [85-88] }\end{array}$ & $\begin{array}{l}\text { Postnatal lethality, growth retardation } \\
{[86,87]}\end{array}$ \\
\hline & BLBP-dependent Nf1 ablation & $\begin{array}{l}\text { Increased glial lineage proliferation, abnormal } \\
\text { neuronal differentiation [89] }\end{array}$ & Postnatal lethality [89] \\
\hline & $\begin{array}{l}\text { Nestin-dependent Nf1 ablation } \\
\text { (induction in adulthood) }\end{array}$ & $\begin{array}{l}\text { Unlocked latent oligodendrocyte lineage, } \\
\text { defective GNP proliferation and migration, } \\
\text { increased adult hippocampal neurogenesis } \\
{[88,90,91]}\end{array}$ & $\begin{array}{l}\text { Spontaneous antidepressive-like } \\
\text { behavior [91] }\end{array}$ \\
\hline \multirow[t]{6}{*}{ Ptpn11 } & Nestin-dependent Ptpn11 ablation & $\begin{array}{l}\text { Decreased neural stem cell proliferation, } \\
\text { lamination defects, reduced number of } \\
\text { neurons, increased number of astrocytes [92] }\end{array}$ & Postnatal lethality, growth retardation [92] \\
\hline & Olig1-dependent Ptpn11 ablation & $\begin{array}{l}\text { Decreased number of oligodendrocyte } \\
\text { precursors and mature oligodendrocytes, } \\
\text { reduced axonal myelination [93] }\end{array}$ & Developmental abnormalities [93] \\
\hline & Olig2-dependent Ptpn11 ablation & $\begin{array}{l}\text { Decreased number of oligodendrocyte } \\
\text { precursors, hypomyelination [94] }\end{array}$ & Postnatal lethality, severe shivering [94] \\
\hline & $\begin{array}{l}\text { Olig2-dependent Ptpn } 11^{\mathrm{Q} 99 \mathrm{R}} \\
\text { knock-in }\end{array}$ & $\begin{array}{l}\text { Increased number of oligodendrocyte } \\
\text { precursors, abnormal myelination [94] }\end{array}$ & Not described \\
\hline & $\begin{array}{l}\text { Nestin-dependent Ptpn } 11^{\mathrm{E} 76 \mathrm{~K}} \\
\text { knock-in }\end{array}$ & $\begin{array}{l}\text { Hydrocephalus, aberrant development of } \\
\text { ependymal cells, reduced proliferation, } \\
\text { enhanced glial differentiation [95] }\end{array}$ & $\begin{array}{l}\text { Postnatal lethality, dome-shaped head, } \\
\text { reduced anxiety behavior, hyperactivity, } \\
\text { impaired motor function [95] }\end{array}$ \\
\hline & Ptpn $11^{\mathrm{D} 61 \mathrm{G}}$ herozygous knock-in & $\begin{array}{l}\text { Increased neurogenesis, decreased } \\
\text { gliogenesis [96] }\end{array}$ & $\begin{array}{l}\text { Impaired synaptic plasticity, impaired spatial } \\
\text { learning, short stature, craniofacial } \\
\text { dysmorphia }[97,98]\end{array}$ \\
\hline Kras & $\begin{array}{l}\text { Synapsin1-dependent Kras } \\
\text { knock-in }\end{array}$ & Enhanced GABAergic synaptogenesis [99] & $\begin{array}{l}\text { Increased inhibitory tone, impaired spatial } \\
\text { learning [99] }\end{array}$ \\
\hline \multirow[t]{2}{*}{ Hras } & Hras $^{G 12 V}$ homozygous knock-in & $\begin{array}{l}\text { Hypertrophy of the brain and pyramidal } \\
\text { neurons [100] }\end{array}$ & $\begin{array}{l}\text { Impaired spatial learning, facial dysmorphia, } \\
\text { cardiac defects [100] }\end{array}$ \\
\hline & $\begin{array}{l}\text { aCaMKIl-dependent } \operatorname{Hras}^{\mathrm{G} 12 \mathrm{~V}} \\
\text { knock-in }\end{array}$ & Increase in docked vesicles [101] & $\begin{array}{l}\text { Increased synaptic plasticity, enhanced } \\
\text { spatial learning [101] }\end{array}$ \\
\hline \multirow[t]{2}{*}{ Braf } & Nestin-dependent Braf ablation & $\begin{array}{l}\text { Impaired neuronal differentiation, } \\
\text { dysmyelination, defective oligodendrocyte } \\
\text { differentiation }[102,103]\end{array}$ & $\begin{array}{l}\text { Postnatal lethality, growth retardation, } \\
\text { defective motor coordination, neuromuscular } \\
\text { defects }[102,103]\end{array}$ \\
\hline & Braf $^{1 / 600 E}$ heterozygous knock-in & $\begin{array}{l}\text { Increased number of GFAP positive cells in } \\
\text { the DG [104] }\end{array}$ & $\begin{array}{l}\text { Reduced life span, growth retardation, facial } \\
\text { dysmorphia, cardiomegaly, epileptic } \\
\text { seizures [104] }\end{array}$ \\
\hline \multirow[t]{2}{*}{ Raf1 } & Raf1 heterozygous knockout & $\begin{array}{l}\text { Small granule cell volume, increased cell } \\
\text { death, reduced neuronal maturation [105] }\end{array}$ & $\begin{array}{l}\text { Postnatal lethality, growth retardation, } \\
\text { apoptosis in the lung and liver, limbs } \\
\text { coordination problems [106] }\end{array}$ \\
\hline & Raf1 $^{\text {L613V }}$ heterozygous knock-in & $\begin{array}{l}\text { Increased density of astrocytes, enhanced } \\
\text { OPCs density [107] }\end{array}$ & Enhanced learning and memory [107] \\
\hline \multirow[t]{4}{*}{ Mek1/2 } & Mek ${ }^{Y 130 C}$ homozygous knock-in & $\begin{array}{l}\text { Increased astrocyte density, increased } \\
\text { number of cortical oligodendrocytes [108] }\end{array}$ & $\begin{array}{l}\text { Pulmonary artery stenosis, cranial } \\
\text { dysmorphia [108] }\end{array}$ \\
\hline & Nestin-dependent Mek1/2 ablation & $\begin{array}{l}\text { Decrease of astrocyte precursors and OPCs, } \\
\text { failure of gliogenesis [109] }\end{array}$ & Early postnatal lethality [109] \\
\hline & hGFAP-dependent Mek1/2 ablation & $\begin{array}{l}\text { Suppressed generation of astrocyte } \\
\text { precursors and OPCs, failure of } \\
\text { gliogenesis [109] }\end{array}$ & Postnatal lethality [109] \\
\hline & hGFAP-dependent Mek $1^{5218 E, 5222 \mathrm{E}}$ & $\begin{array}{l}\text { Increase in astrocyte precursors and mature } \\
\text { astrocytes, reduction of neuron number [109] }\end{array}$ & Not described \\
\hline
\end{tabular}


oligodendrocyte precursor cells [131-133]. Therefore, during normal early developmental stages, RAS-ERK signaling activity is kept low so that Neurog2 is able to promote glutamatergic neuronal differentiation of embryonic cortical progenitors. However, in an abnormal context where the RAS-ERK signaling is elevated, Neurog2 expression is switched to Ascl1 expression [134]. During moderate activation of RAS-ERK signaling, Ascl1 expression promotes GABAergic neuronal differentiation, while Ascl1 promotes proliferative glioblast phenotypes when RASERK signaling is highly active [134].

RAS interacts with and regulates other signaling pathways in addition to the MEK/ERK cascade. As one of the main effector pathways of RAS, the phosphatidylinositol 3-kinase (PI3K)-AKT pathway regulates protein synthesis and variety of cellular processes such as cell growth, cycle entry, and cellular survival [135-137]. The Ras and PI3KAKT pathway were shown to activate and inhibit each other via multiple cross-talks [138]. Studies using rodent models have reported distinct phenotypes and revealed a pivotal role of PI3K signaling in nervous systems. For instance, deleting a PI3K isoform PI3K $\gamma$ in mice impaired synaptic plasticity and behavioral flexibility, while its overexpression through viral vector resulted in impaired synaptic plasticity and spatial learning [139, 140]. The Janus kinase (JAK)-signal transducer and activator of transcription (STAT) pathway is also a well characterized cascade known to interact with RAS-ERK [141]. JAK activation stimulates cell proliferation, differentiation, cell migration and apoptosis, and there are compelling evidences that JAK-STAT pathway plays essential roles in synaptic plasticity [142].

\section{RASopathies and central nervous system development Neurofibromatosis type 1}

Neurofibromatosis type 1 (NF1) is a relatively common developmental disease that affects 1 in 3,000 individuals and is diagnosed by both somatic and behavioral symptoms $[20,143]$. NF1 is caused by loss of function mutations in NF1 alleles [10, 143, 144]. The NF1 gene encodes a GAP for RAS, neurofibromin, which promotes the conversion of active RAS-GTP to inactive RAS-GDP, thus, negatively regulating the RAS-ERK signaling pathway $[145,146]$. Therefore, loss of function mutations in NF1 result in the hyperactivation of RAS-ERK signaling. As mutations in the NF1 gene lead to abnormal cell growth, proliferation, and differentiation, individuals with NF1 frequently display neurofibromas, hyperpigmentation of melanocytes, and hamartomas of the iris $[17,18]$. Additionally, common features of NF1 include bone malformations, cardiac defects, and neurocognitive impairments [19,20]. More than $75 \%$ of NF1 patients suffer from cognitive deficits, such as below-average IQ and specific deficits in attention, executive functioning, and visual-spatial skills $[15,16]$.
Although tumor development in the peripheral nervous system is a hallmark of NF1, a variety of CNS abnormalities, including neurofibroma, have been reported in NF1 patients [147]. For example, abnormal cortical lamination and a compressed cerebral cortex were observed in the brains of NF1 patients, indicating a critical role for NF1 in cortical development [13]. Interestingly, several studies have also suggested that NF1 is associated with deficits in glial development. For example, children with NF1 display abnormalities in astrocyte growth regulation and tend to develop astrocytoma [14, 148]. Similarly, a postmortem study reported that three NF1 brains exhibited extensively increased astrogliogenesis [149]. Specifically, an association between an enlarged corpus callosum and severe learning disabilities in a subpopulation of NF1 patients has been reported [150, 151]. Moore and colleagues also reported that the total brain volume, especially the gray matter, was significantly larger in NF1 subjects than in children and adolescents without NF1. The gray matter volume in NF1 subjects was inversely correlated with their degree of learning disability [150]. Taken together, individuals with NF1 display CNS developmental abnormalities, including promoted astrogliogenesis and structural malformation, which might be associated with learning disabilities.

$N f 1$ homozygous knockout mice $\left(\mathrm{NfI}^{-1-}\right)$ die in utero because of severe heart malformations, a delay in renal, hepatic, and skeletal muscle development, and hyperplasia of neural crest-derived sympathetic ganglia [76, 77]. In addition, Nf1-deficient mouse embryos exhibit defects in the neural tube, including exencephaly or the thinning of the dorsal telencephalic wall, although the targeted allele in this study was slightly different from previous investigations [75]. Therefore, a heterozygous knockout mouse line $\left(\mathrm{Nf}^{+/-}\right)$has been extensively used to investigate the cellular mechanisms underlying NF1 etiology [80, 81, 83, 84, 152, 153]. Silva and colleagues showed that $\mathrm{Nf}^{+/-}$mice display impaired spatial learning and impaired hippocampal synaptic plasticity [80, 81]. Mechanisms underlying the deficits in learning and synaptic plasticity in NF1 mouse models have been extensively reviewed in previous publications $[8,154]$. In line with human patients, $N f 1$ heterozygous mutant mice showed developmental abnormalities in the heart and neural crest-derived tissues, and an increased number of astrocytes with high levels of glial fibrillary acidic protein (GFAP) in the periaqueductal grey, nucleus accumbens, and hippocampus [76, 79].

Ablation of Nf1 only in neurons by using the Synapsin I promoter $\left(N f 1^{\mathrm{Syn} 1}\right)$ led to growth retardation, including reduced body weight and size, that was sustained into adulthood [83]. Nf1 ${ }^{\mathrm{Syn} 1}$ conditional knockout (CKO) mice exhibited reduced size and weight of the forebrain, but not other brain regions [83]. Histological analyses of 
CKO mice also revealed remarkable defects in the cerebral cortex, such as a reduction in cortical thickness [83]. Neuronal loss in mutant cortices was not detected; however, interestingly, CKO mice displayed extensive GFAP immunoreactivity throughout the cerebral cortex, hippocampus, and brainstem, which indicates increased astrogliogenesis [83]. These results indicate that $N f 1$ has an indispensable role in CNS development, and that Nf1-deficient neurons induce astroglial hypertrophy and GFAP induction through a paracrine effect $[83,155]$.

Several studies suggested that neurofibromin might be required for NSCs or neuroglial progenitor function, and that Nf1 mutations affect both astroglial and neuronal lineages. Studies using a well-characterized human GFAP (hGFAP)-Cre transgenic mouse line have demonstrated that Nf1 plays a critical role in CNS development. Typically, hGFAP-Cre expression is first detected in radial glia, which give rise to both neuronal and glial lineage cells, around embryonic day 13 [156]. Mutant $N f 1^{\text {hGFAP }}$ CKO mice, which lack neurofibromin in the majority of their cortical neurons and astrocytes, were born in normal numbers, but became noticeably smaller than their littermates over time, and typically died by four months of age $[86,87] . N f 1^{\text {hGFAP }}$ CKO mice displayed enlarged cerebral cortices and an increased brain to body weight ratio caused by the enlarged cortex $[85,88]$. The mutant mice also exhibited a notably smaller cerebellum, compared with littermates, and defective migration and proliferation of granule neuron progenitors [88]. In addition, $N f 1^{\text {hGFAP }}$ CKO mice failed to form cortical barrels in the somatosensory cortex, although segregation of thalamic axons within the somatosensory cortex was unaffected [87]. Consistent with NF1 patients, the mutant mice displayed increased GFAP-positive astrocytes throughout both the gray and the white matter, including the corpus callosum and anterior commissure [86]. Wang and colleagues also showed that the $N f 1^{\text {hGFAP }}$ CKO mice display increased gliogenesis at the expense of neurogenesis in the neonatal period and during adulthood [85]. Due to the altered ratio of glia to neurons, $N f 1^{\mathrm{hGFAP}}$ CKO mice displayed a smaller olfactory bulb and an enlarged corpus callosum, providing a link between brain structural abnormalities and cognitive impairments in animal models and those seen in NF1 patients [85]. Similarly, Nf1 inactivation in neuroglial progenitors using a brain lipid binding protein (BLBP)-Cre mouse strain also led to increased glial proliferation and abnormal neuronal differentiation in vivo [89]. However, it is also noteworthy to mention that deleting $N f 1$ using GFAP-Cre did not impair either learning or synaptic plasticity in adult mice [84].

Recent studies reported that $N f 1$ regulates cell fate specificity and cellular processes in both the developmental stage and in adulthood. Inactivation of Nf1 in adult NSCs unlocked a latent oligodendrocyte lineage and allowed NSCs to produce all three lineages in vivo [90]. Similarly, postnatal Nf1 ablation using NestinCreERT2 was sufficient to cause cerebellar abnormalities, including defective cerebellar foliation, granule neuron progenitors (GNPs) proliferation, and migration [88]. Also, deletion of $N f 1$ in adult hippocampal neural progenitor cells led to enhanced proliferation and an increase in new neurons in the dentate gyrus [91].

Since Nf1 also functions as a tumor suppressor gene, in vitro studies in various cell types have suggested that Nf1 mutations are associated with growth abnormalities, such as increased proliferation of oligodendrocyte precursors in the embryonic spinal cord [157] and Schwann cells [158]. Particularly, $\mathrm{Nf1}^{-/-}$and $\mathrm{Nf1}^{+/-}$NSCs generate increased numbers of morphologically abnormal, immature astroglial cells in vitro [159]. The increase in astroglial progenitors and proliferating cells seen in vitro was also observed in $N f 1^{-1-}$ and $N f 1^{+-}$embryonic brains and $\mathrm{NfI}^{+/-}$adult brains in vivo [159]. In addition, Lee and colleagues showed that $\mathrm{Nf}^{-1-}$ NSCs from the brainstem exhibit increased proliferation and glial cell differentiation in vitro and in vivo; however, the lack of effect on neocortex NSCs proliferation or gliogenesis suggests that the effects of $N f 1$ gene inactivation are brain regionspecific [160].

What would be an underlying mechanism for the enhanced glial population in NF1? It has been demonstrated that Nf1 inactivation in neural stem/progenitor cells can alter glia/neuron fate specification by promoting the expression of Olig2, a basic-helix-loop-helix transcription factor that is required for oligodendrocyte progenitor cell specification [161]. $N f 1^{\text {hGFAP }}$ CKO and $N f 1^{\text {BLBP }}$ CKO mutant mice showed increased Olig2 expression, suggesting that Nf1 suppresses Olig2 expression and the oligodendrocyte progenitor lineage in neonatal subventricular zone progenitor cells $[85,160]$. In concordance with the neonatal study, inactivation of Nf1 in adult NSCs also resulted in increased Olig2 expression [90]. In conclusion, these studies with $N f 1$ mutant mice revealed the essential role of NF1 in CNS development, including the gross morphology and proper formation of several brain region structures, and the regulation of cell fate.

Along with structural abnormalities in CNS, several lines of evidence suggest that the distribution of NF1 in single neuronal cell type may also contribute to cognitive deficits in NF1. Transcriptome analyses of mouse brain have unveiled the enriched NF1 expression in inhibitory neurons rather than the in excitatory neurons, and provided a clue as to how NF1 mainly carries out its role in inhibitory synaptic function [162]. Furthermore, based on the conserved expression pattern of NF1 in human brain, it is suggested that the enriched expression of NF1 in inhibitory neurons may underlie cell type-specific pathophysiology and cognitive deficits in NF1 [163]. 
Nf1 mutant mice mimic most of the CNS features found in NF1 human patients, including increased brain volume, enlarged corpus callosum and cortical area, and especially, enhanced gliogenesis, which may be closely associated with structural abnormalities. Despite compelling evidences of the expression of glial lineage transcription factors such as Olig2 increasing as RAS-ERK highly activates $[85,90,108]$, yet it is unclear how RASERK pathway regulates cell fate determinants. Thus, for understanding CNS abnormalities in NF1 patients, it is worth investigating the expression regulations of cell fate determinants with regard to RAS-ERK activity.

\section{Noonan syndrome and Noonan syndrome with multiple lentigines}

Noonan syndrome (NS) is an autosomal dominant genetic disorder with an incidence of 1 in 2,500 live births $[31,164,165]$. This complex disorder occurs both in familial and sporadic forms [166]. Germline mutations in genes involved in RAS-ERK signaling pathway have been reported to be associated with NS, such as the gain of function mutations in protein tyrosine phosphatase nonreceptor type 11 (PTPN11), son of sevenless homolog 1 (SOS1), Kirsten rat sarcoma viral oncogene homolog (KRAS), neuroblastoma RAS viral oncogene homolog (NRAS), Raf-1 proto-oncogene (RAF1), BRAF, soc-2 suppressor of clear homolog (SHOC2), and MEK1, and the loss of function mutations in $\mathrm{Cbl}$ proto-oncogene $(C B L)$ $[25,63,167]$. Above all, mutations in PTPN11, which encodes the non-receptor protein phosphatase SHP2, account for approximately $50 \%$ of NS cases [167]. Patients with NS are characterized by typical facial abnormalities, such as a broad forehead, sparse eyebrows, a low-set and posteriorly rotated ear, and a webbed neck, while other important features include a short stature, motor delay, increased risk of cancer, and cardiac defects [34-40]. Noonan syndrome with multiple lentigines (NSML) patients have most of the clinical symptoms observed in individuals with NS, but they also display increased penetrance of hypertrophic cardiomyopathy and lentigines [168]. Distinct from NS, PTPN11 loss of function mutations result in NSML [168].

Between $30 \%-50 \%$ of NS patients show a variable degree of neurocognitive delay, but there are relatively few reports of CNS malformations in NS individuals [34, 35]. Two cases of NS were reported to be associated with cerebellar ectopia $[28,29]$. In addition, there are several reports of NS being associated with a temporal lobe anomaly, hydrocephalus, cerebral abscess, and malignant Schwannoma [30-32]. In particular, Saito and colleagues reported one case of an NS patient with severe mental retardation and intractable epilepsy [33]. The patient also displayed cortical dysplasia, including dilated perivascular spaces and a dysplastic lesion in the left temporal lobe [33].
Mutant mice harboring NS-associated Sos ${ }^{\text {E846K }}$, Kras $^{\mathrm{V} 14 \mathrm{I}}$, and Raf1 ${ }^{\mathrm{L} 613 \mathrm{~V}}$ displayed a short stature, facial dysmorphia, growth retardation, and cardiac defects, which are characteristic features of NS patients [169-172]. Since PTPN11 mutations are the majority among NS cases, Shp2 mutant mice are one of the most studied models of NS [96-98, 173, 174]. A subpopulation of NS patients have a constitutively active mutation Shp2 ${ }^{\mathrm{D} 61 \mathrm{G}}$, which has a highly increased phosphatase activity $[175,176]$. The homozygous Shp2 ${ }^{\text {D61G }}$ mutation was eventually embryonically lethal, as the embryos were grossly hemorrhagic and edematous, showed a decreased liver size, and had cardiac defects [98]. However, half of heterozygous Shp2 ${ }^{\mathrm{D} 61 \mathrm{G}}$ mice that carried only one copy of the mutant allele $\left(\mathrm{Shp} 2^{\mathrm{D} 61 \mathrm{G} /+}\right)$ survived, and displayed a short stature and craniofacial dysmorphia, such as wide-set eyes, a broad forehead, and a triangular face, which were similar to NS patients [98]. Heterozygous Shp2 ${ }^{\text {D61G }}$ mice also showed deficits in spatial learning and memory and had impaired synaptic plasticity [97]. Mice carrying a milder mutation, Shp2 ${ }^{\mathrm{N} 308 \mathrm{D}}$, displayed some cardiac defects and mild impairment to spatial learning and memory that was consistent with human cases [97, 98]. Neural crest cell-specific Shp2 ${ }^{\mathrm{Q} 79 \mathrm{R}}$ resulted in craniofacial defects and growth retardation [170]. Neural stem cellspecific expression of Shp2 ${ }^{\mathrm{E} 76 \mathrm{~K}}$ by using Nestin-Cre resulted in hydrocephalus due to aberrant development of ependymal cells [95]. In addition, Shp2 ${ }^{\mathrm{E} 76 \mathrm{~K}}$-expressing mice showed hyperactivity accompanied by reduced anxiety behavior, and impaired motor function [95]. Global Shp2 ${ }^{\mathrm{D} 61 \mathrm{Y}}$ expression resulted in embryonic lethality, while epiblastspecific Shp2 ${ }^{\mathrm{D} 61 \mathrm{Y}}$ expression induced embryonic cardiac defects [173].

SHP2 is a growth factor-regulated phosphatase that modulates both the RAS-ERK and the gp130-JAK-STAT pathways $[177,178]$. Since both pathways are known to play critical roles in cell proliferation and differentiation, several studies demonstrated that SHP2 affects cell proliferation and differentiation in large range of cell types [179-183]. For example, SHP2 is required for the initiation of retinal neurogenesis and it regulates the patterning of optic vesicles by mediating retinal progenitor factors and cell proliferation [184]. Huang and colleagues have shown that the suppression of SHP2 activity reduces cell migration and neurite outgrowth, and that it decreases the differentiation-induced activation of FAK, Src, paxillin, and ERK1/2 [185]. Also, the authors demonstrated that SHP2 is recruited to focal adhesions in NSCs and that it regulates focal adhesion formation [185].

Recent studies have suggested that Shp2 is involved in oligodendrocyte development in the telencephalon. In vitro studies using rat cortical cultures demonstrated different roles for Shp2 in either oligodendrocyte precursor cell proliferation or maturation [186, 187]. The in vivo function of Shp2 in oligodendrocyte differentiation was 
also investigated by Zhu and colleagues using conditional mutant mice with a selective Shp2 deletion in Olig1-expressing cells in the ventral spinal cord [93]. The mutant mice displayed a dramatic reduction in the number of both oligodendrocyte precursor cells and mature oligodendrocytes and decreased axonal myelination in the developing CNS, suggesting that Shp2 is a critical regulator of oligodendrocyte proliferation and differentiation [93]. Similarly, Ehrman and colleagues investigated the role of Shp2 in ventricular zone progenitor cells of the ventral telencephalon and in cells of the oligodendrocyte lineage by deleting Shp2 in Olig2-positive cells [94]. Olig2-specific Shp2 null mutant mice showed a significant decrease in the number of oligodendrocyte progenitor cells, at embryonic and postnatal stages, and severe hypomyelination [94]. Moreover, expressing an NS-associated mutation Shp2 ${ }^{\mathrm{Q} 79 \mathrm{R}}$ using Olig2-Cre increased the number of oligodendrocyte precursor cells in the embryonic and postnatal brain, but also induced abnormal myelination and fewer myelinated axons in the white matter [94].

SHP2 has been shown to play a role in cell fate decisions as it promotes neurogenesis and suppresses astrogliogenesis through the repression of the JAK-STAT pathway, which is required for astrocyte formation in the developing brain. Gauthier and colleagues reported that germline Shp $2^{\mathrm{D} 61 \mathrm{G}}$ heterozygous mice showed more neurons and fewer astrocytes in the hippocampus and dorsal cortex at postnatal day 2, and suggested that NSassociated mutations cause brain abnormalities by disrupting the balance of CNS populations [96]. Ke and colleagues also demonstrated that SHP2 is an important player in mammalian brain development by generating a novel mutant mouse in which Shp2 is selectively eliminated in neural precursor cells [92]. The mutant mouse showed early postnatal lethality, decreased proliferation of NSCs, and lamination defects in the developing cerebral cortex [92]. Mutant mice showed a reduced number of neurons and an increased number of astrocytes, which imply defective neuronal differentiation and modestly enhanced astrogliogenesis, supporting the idea that Shp2 promotes neurogenesis and suppresses astrocytogenesis [92]. The peripheral nervous system of Wnt1Cre or Krox20-Cre conditional Shp2 floxed mice displayed severe deficits in Schwann cell development and the hypomyelination of peripheral nerves [188].

There are other NS mouse models in addition to Shp2 mutant mice. Heterozygous Raf1-deficient mice display smaller granule cell layer volumes at postnatal day 30 and a substantial number of abnormal, chromophilic, fast dividing cells in the subgranular zone and dentate gyrus [105]. In addition, Raf1-deficient neural progenitor cells showed an increased rate of cell death and reduced neuronal maturation [105]. Recently, Holter and colleagues reported that mice expressing the NS-associated gain of function mutation $\operatorname{Raf} 1^{\mathrm{L} 613 \mathrm{~V}}$ have a significantly greater density of GFAP-positive astrocytes in the cortex and hippocampus. In addition, the number of Olig-positive oligodendrocyte progenitor cells were also increased in cortical area of Raf1 ${ }^{\mathrm{L} 613 \mathrm{~V}}$ mutant mice [107]. Interestingly, Raf $1^{\mathrm{L} 613 \mathrm{~V}}$ mice showed enhanced performance in several learning tasks [107]. NS-associated Kras ${ }^{\mathrm{G} 12 \mathrm{~V}}$ mutant mice showed enhanced GABAergic synaptogenesis and impaired spatial learning when the mutation was selectively expressed in synapses [99].

Although it is known that transcription factors for glial lineage become highly expressed in accordance with increasing RAS-ERK activity [85, 90, 108], RAS-activating mutation $\mathrm{SHP} 2^{\mathrm{D} 61 \mathrm{G}}$ promotes neuronal lineage rather than glial lineage, by direct interaction with JAK-STAT pathway [96]; however, the expression of glial transcription factors that may have been affected by the increase in RAS-ERK activity is yet to be examined. On the contrary, other NS-linked mutations such as $\mathrm{Rafl}^{\mathrm{L} 613 \mathrm{~V}}$ rather enhanced glial lineage [107]. Although the underlying mechanism for the discrepancy in cellular phenotypes is not clear, these results suggest that there are distinct pathophysiology according to each NS-associated mutation. It would be interesting to examine the neuron-glia ratio in either NS patient-derived iPSCs or postmortem brain tissues harboring specific PTPN11 or RAF1 mutations.

\section{Cardio-facio-cutaneous syndrome}

Cardio-facio-cutaneous syndrome (CFCS) is a rare RASopathy that is caused by mutations in the genes that encode downstream effectors of RAS [41, 42, 44], including BRAF [41, 42], KRAS [41], and MEK1/2 [42]. Importantly, heterozygous BRAF mutations are found in over $70 \%$ of CFCS patients [58]. BRAF encodes a serine/threonine kinase, and, interestingly, both the kinase-active and kinaseimpaired mutations of BRAF are associated with CFCS $[41,42]$. Heterozygous missense mutations in $M E K 1$ and $M E K 2$ are found in approximately $25 \%$ of CFCS individuals [58]. MEK1 and $M E K 2$ are threonine/tyrosine kinases, and all the $M E K$ mutants associated with CFCS are activating mutations $[42,189]$. CFCS patients display multiple congenital abnormalities which overlap with those seen in NS and Costello syndrome, including craniofacial defects, hypertrophic cardiomyopathy, pulmonary artery stenosis, and neurocognitive delay [58]. CFCS individuals exhibit NS-like faces, with macrocephaly, low-set ears, a short nose, a broad forehead, and down-slanting palpebral fissures with ptosis $[4,59]$. Cardiac abnormalities are also similar to those of NS and Costello syndrome, with pulmonic stenosis, septal defects, and hypertrophic cardiomyopathy (HCM) having the highest prevalence [59]. Neurological abnormalities, including hypotonia, motor delay, seizures, tactile defensiveness, speech delay, and 
learning disabilities, are present at varying degrees $[4,50,55]$. Failure to thrive caused by gastrointestinal dysfunction, including vomiting, oral aversion, reflux, and constipation, is also typical in CFCS individuals in infancy [50]. However, CNS abnormalities are significant diagnostic features of CFCS. Previous studies reported the abnormalities in brain structures, including ventriculomegaly and hydrocephalus, in CFCS patients [44-50]. Volume loss in the brain due to cortical atrophy, cerebral atrophy, brain stem atrophy, and white matter atrophy have also emerged in a subpopulation of patients [44, 46, 51-54]. Additionally, migration abnormalities, myelination abnormalities, and corpus callosum abnormalities, such as hypoplasia and lipoma were also revealed by brain imaging [50, 52, 55-57]. In line with brain abnormalities, most CFCS patients are diagnosed with varying degrees of cognitive deficits and intellectual disabilities [50].

Recently, patient-derived induced pluripotent stem cells (iPSCs) have contributed to advancements in the understanding of disease-associated mutations. Yeh and colleagues generated iPSC from a patient harboring $B R A F^{\mathrm{Q} 257 \mathrm{R}}$, the most frequent CFCS mutation [190]. This mutation resulted in a depletion of neural progenitor pool, induced by decreased phosphorylation of AKT, and early neuronal maturation [190]. Due to the depletion of progenitors, the number of late-born cells, such as the upper-layer cortical neurons and glia, was decreased [191]. The number of GABAergic interneurons was increased, indicating that the high prevalence of seizures in CFCS individuals may be caused by an imbalance between excitation and inhibition [191].

Fewer animal models of CFCS have been reported likely due to its lower prevalence ( 1 in 810,000 ) compared to other RASopathies. Transgenic mouse models carrying gain of function mutations that are associated with CFCS recapitulate multiple aspects of human CFCS patients $[108,192]$. Since $B R A F$ is the most prevalent gene that is mutated in CFCS, a majority of animal studies in CFCS have focused on Braf. Prior to the review of gain of function mouse models associated with CFCS, we first reviewed loss of function studies that investigated the role of Braf in various biological processes. Wiese and colleagues identified that cultured embryonic sensory and motor neurons lacking Braf could not survive in the presence of neurotrophic factors while Raf1deficient neurons could survive, suggesting that Braf is essential for survival [193]. A Braf null mutant mouse was embryonically lethal due to the vascular defects at midgestation [194]. In addition, the ablation of Braf in NSCs using Nestin-Cre resulted in abnormal morphogenesis of the CNS, such as a decreased cerebellum with fuzzy granule cell layer borders and a diminished hippocampus granule cell layer, due to reduced differentiation of dentate gyrus progenitor cells into mature granule cell neurons [102]. Nestin-Cre specific Braf-deficient mice also displayed severe dysmyelination and defective oligodendrocyte differentiation, implicating Braf in postnatal CNS development [103]. Forebrain excitatory neuronspecific Braf knockout mice showed deficits in hippocampal long-term potentiation and impaired hippocampaldependent learning and memory, while the impact of Braf deletion on CNS development in this knockout remains to be investigated [195].

The first mutant mouse model of CFCS was a knockin of the constitutively active form of Braf, Braf ${ }^{\mathrm{V} 600 \mathrm{E}}$, which recapitulates several CFCS characteristics, including a reduced life span, growth retardation, facial dysmorphia, cardiomegaly, and epileptic seizures [104]. Mice expressing the conditional knock-in $B r a f^{L 597 \mathrm{~V}} \mathrm{mu}$ tation also recapitulated CFCS symptoms of a short stature, facial dysmorphia, and cardiac enlargement [196]. The most prevalent CFCS mutation, Braf ${ }^{\mathrm{Q} 241 \mathrm{R}}$, induced embryonic/neonatal lethality with multiple congenital defects that included embryonic skeletal abnormalities, lymphatic defects, cardiac defects, and liver necrosis in the C57BL/6J background, and lethality between birth and 24 weeks, growth retardation, sparse and ruffled fur, liver necrosis, and atrial septal defects on the mixed background (BALB/c and C57BL/6J) [192, 197]. In addition, Braf $\mathrm{Q}^{\mathrm{Q} 41 \mathrm{R} / \mathrm{-}}$ mice showed growth retardation, a hunched appearance, craniofacial dysmorphism, and learning deficits on ICR background [192].

Mouse models carrying Mek $1^{\mathrm{Y} 130 \mathrm{C}}$, the most common MEK1 mutation in CFCS patients, showed increased ERK activation in response to growth factors, pulmonary artery stenosis, cranial dysmorphia, and neurological anomalies [108]. Moreover, Mek1 $1^{\mathrm{Y} 130 \mathrm{C} / \mathrm{Y} 130 \mathrm{C}}$ mice showed a higher density of GFAP-positive astrocytes in the sensory cortex and hippocampal CA1 regions [108]. In addition, the total cortical oligodendrocyte population, as analyzed by Olig2 immunolabeling, was increased in the sensory cortex of $M e k 1^{\mathrm{Y} 130 \mathrm{C} / \mathrm{Y} 130 \mathrm{C}}$ mice [108]. As addressed earlier, patients-derived iPSC containing $B R A F^{\mathrm{Q} 257 \mathrm{R}}$ exhibited early neuronal maturation and decreased late-born glial populations, whereas either CFCS-associated Mek1 ${ }^{\text {Y130C }}$ or $B r a f^{V 600 E}$ expressing adult mice exhibited an increased number of GFAP-positive cells in hippocampal and cortical areas $[104,108,190]$. Although, $B R A F^{\mathrm{Q} 257 \mathrm{R}}$ is a gain of function mutation, the activation of ERK was decreased in neural progenitor cells, which might have been due to cell context-dependent role of $B R A F$, and these results indicate that the decreased ERK activation may be responsible for the decreased glia in $B R A F^{\mathrm{Q} 257 \mathrm{R}}$ iPSCs [190]. In addition to mouse models, zebrafish models expressing CFCS Braf or Mek variants were also generated, and these CFCS mutant alleles interfered with convergenceextension cell movements during gastrulation to cause 
similar developmental phenotypes [189]. Taken together, each of the CFCS-associated genes play essential roles in CNS development, including oligodendrocyte precursor maturation and proliferation, myelination, and neuronal differentiation. However, our knowledge regarding the causal relationship between CNS abnormalities and cognition in CFCS is still limited. Further studies using mutant animals with more specific temporal and spatial manipulation of CFCS genes would provide understanding of the pathophysiology of cognitive deficits in CFCS.

\section{Costello syndrome}

Costello syndrome (CS) is a rare multiple congenital abnormality syndrome that affects 1 in 1,250,000 people and shares many features with other RASopathies [198-200]. CS is mostly caused by gain of function mutations in the $H R A S$ gene, most of which have been previously reported as somatic or oncogenic mutations in various tumors [60, 62, 201]. HRAS activating mutations are highly prevalent in CS individuals; they disrupt guanine nucleotide binding and induce a decrease in intrinsic and GAPinduced GTPase activity, allowing mutant HRAS proteins to remain in the active state [202]. In addition, $B R A F$, $K R A S$, and MEK1 mutations are also associated with a small population of CS individuals [27, 63, 203]. CS patients are typical characterized by coarse facial features, redundant and loose skin, severe failure to thrive, mental retardation, cardiomyopathy, and a predisposition to tumors $[59,60]$. There is no single feature that is unique to CS, and this syndrome phenotypically overlaps with NF1, NS, NSML, and CFCS [60, 204]. Typical and coarse facial features associated with CS involve macrocephaly with a prominent forehead, a short nose with a depressed nasal bridge and a broad base, and low-set, posteriorly rotated ears with thickened helices and lobes. Most CS patients have cardiac abnormalities, including hypertrophic cardiomyopathy, valve abnormalities, septal defects, and arrhythmia [205]. Failure to thrive due to gastrointestinal dysfunction often involves reflux, oral aversion, and constipation during early infancy $[67,200]$. Structural and electrophysiological neurological malformations are also common in CS. For example, ventricular abnormalities, such as mild ventricular dilatation, are observed in more than $40 \%$ of CS individuals [64-67]. Cerebral malformations in CS include cerebral atrophy, leukomalacia, poor gray-white matter differentiation, a small corpus callosum, and MRI signal abnormalities [64, 65, 67-71]. Cerebellar abnormalities include malformation, cerebellar atrophy, deviation of the cerebellar tonsils, and demyelinization of the basal tonsil [66, 69, 71-74].

Krencik and colleagues have shown that human iPSCs carrying $H R A S^{\mathrm{G} 12 \mathrm{~S}}$ that were derived from CS patients exhibited hyperplasia and differentiated into astroglia more rapidly in vitro than iPSCs derived from control cell lines with normal HRAS. CS-derived iPSCs also generated an abundance of extracellular matrix remodeling factors and proteoglycans [206]. Moreover, $H R A S^{\mathrm{G} 12 \mathrm{~S}}$ iPSC-derived neurons had a longer progenitor phase, unlike the phenotype reported in $B R A F^{\mathrm{Q} 257 \mathrm{R}}$ iPSCderived neurons that originated from CFCS patients [190, 207]. Thus, postnatal progressive cerebellar overgrowth of the brain in CS individuals could be caused by the extended progenitor phase [208].

As with CFCS, only few animal models were generated for CS. Both homozygous and heterozygous $\mathrm{Hras}^{\mathrm{G} 12 \mathrm{~V}}$ knock-in mice closely phenocopied some of the features observed in individuals with CS, including facial dysmorphia, cardiomyopathies, and alterations to the homeostasis of the cardiovascular system [209]. In addition, later studies with homozygous $\mathrm{Hras}^{\mathrm{G} 12 \mathrm{~V}}$ knock-in mice demonstrated that they have neurocognitive deficits, such as hyperactivity, increased anxiety-like behavior and mild deficit in spatial memory [210]. However, Viosca and colleagues did not observe significant changes in either the activity or the expression of downstream of Hras such as phospho-CREB and c-fos [210]. Transgenic mice with forebrain excitatory neuron-specific expression of Hras $^{\mathrm{G} 12 \mathrm{~V}}$ under the control of the $\alpha \mathrm{CaMKII}$ promoter displayed several synaptic phenotypes, including a high density of docked neurotransmitter vesicles in glutamatergic terminals and increased synaptic plasticity which may be associated with the dramatically enhanced hippocampaldependent learning [101]. Schreiber and colleagues have also shown that the homozygous $\mathrm{Hras}^{\mathrm{G} 12 \mathrm{~V}}$ knock-in mice exhibit spatial learning deficits, which are accompanied by robust upregulation of Erk signaling in hippocampal lysates, neuronal hypertrophy, increased brain volume, and impaired mGluR-dependent long-term depression (LTD) [100]. Notably, mice expressing CS-associated Hras ${ }^{\text {G12V }}$ or $\mathrm{Hras}^{\mathrm{G} 12 \mathrm{~S}}$ mutations in cortical precursors displayed promoted precursor cell proliferation and premature gliogenesis, but inhibited neurogenesis [211]. Consistently, either form of Hras mutations also promoted precursor cell proliferation and astrogenesis, but inhibited neurogenesis in cultured cortical precursors [211]. These findings from multiple experimental systems such as iPSCs, mice models and cultured cells commonly suggest the essential role of HRAS in neural precursor cell proliferation and gliogenesis, which might strongly affect the structure and function of CNS including increased brain volume in CS patients.

\section{Concluding remarks}

Here, we reviewed that mutations in different components of the RAS-ERK signaling pathway associated with different RASopathies have distinct impacts on CNS development in a cell type-specific manner (Fig. 2). However, it is still unclear how some mutations affect 


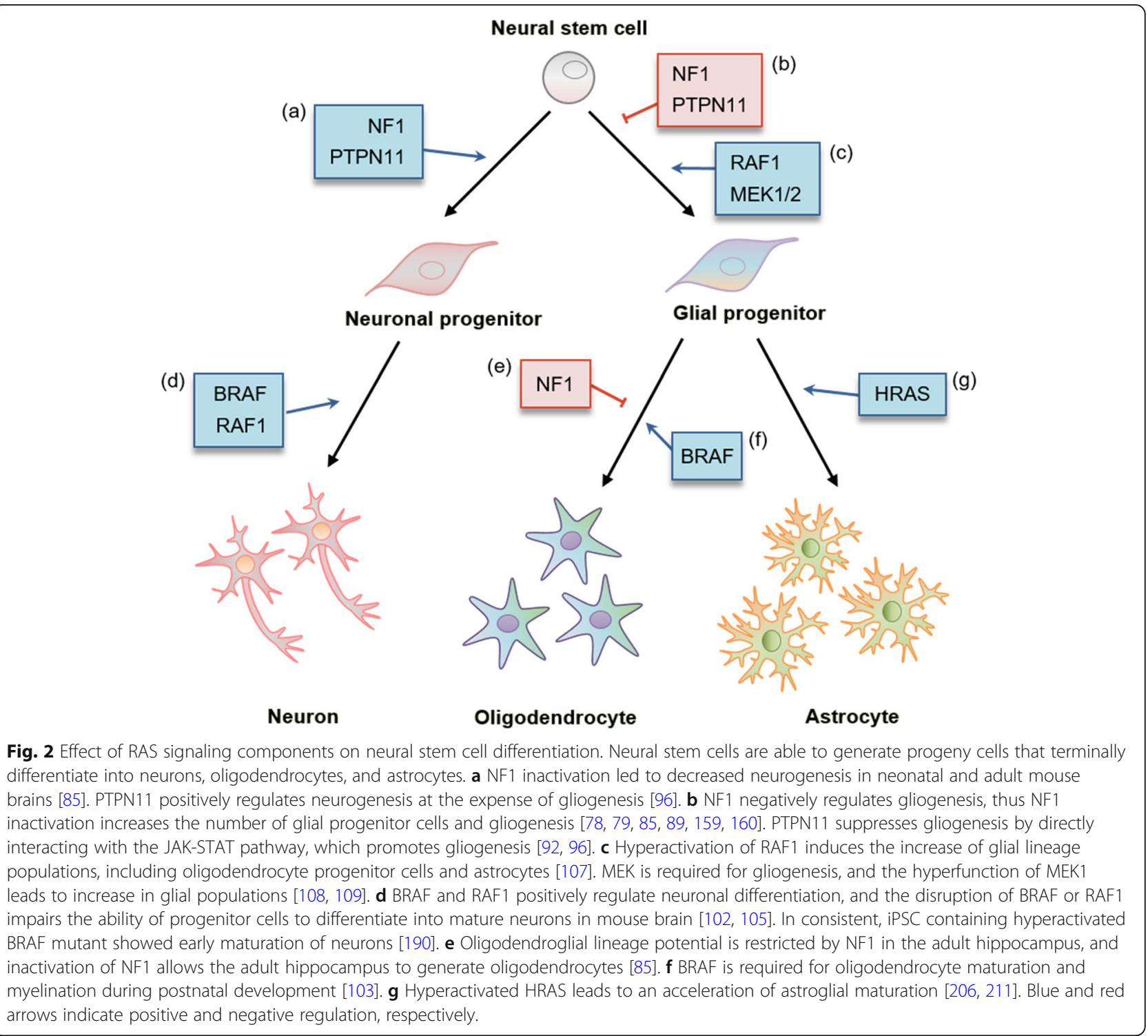

neurons and others affect glia. One hypothesis is that different signaling molecules are expressed at distinct phases during development. So far, we do not have the expression profiles of RAS signaling molecules during brain development in high spatial and temporal resolution. However, most of the key RAS-ERK components, such as NF1, SHP2, BRAF, and MEK1/2, begin to be expressed before either embryonic day 10 or 15, which are initiation time points of neurogenesis or astrogliogenesis, respectively [212]. Recently, it has been shown that the expression of RAS-ERK signaling molecules was remarkably different between excitatory and inhibitory neurons in mouse hippocampus [162]. Thus, it would be interesting to examine whether the expression levels of various signaling molecules are differentially regulated in NSCs over different developmental stages. Advanced tools, such as single cell RNA-seq, might be useful to answer this question. It should also be considered that there are multiple cross-talks between RAS and other signaling pathways. Different components in RAS signaling interact with distinct signaling networks, which may account for the cell type-specific developmental deficits in each RASopathy.

Treatments for the cognitive deficits found in RASopathies are not available yet. Since most RASopathyassociated mutations increase RAS-ERK activation, downregulating the activity of RAS or its downstream effectors is an obvious strategy to develop treatments for RASopathies. Although statins, which can reduce RAS activity by inhibiting the farnesylation of RAS, have been proposed for the improvement of learning disabilities in NF1 children [213], the results from various clinical trials have been inconsistent [214-216]. The reason for these discrepant results remains unclear. However, considering the 
ubiquitous expression of RAS in many cell types and multiple organs, directly regulating RAS activity may have unknown confounding effects. Thus, it would be better to target specific molecules other than RAS in a diseasespecific manner. For example, Omrani and colleagues showed that inhibitory neuron-specific attenuation of hyperpolarization-activated cyclic nucleotide-gated ( $\mathrm{HCN})$ currents can be an underlying mechanism for the cognitive deficits in $\mathrm{Nf1}^{+/-}$mice when they used an $\mathrm{HCN}$ agonist to rescue cognitive deficits in $N f 1^{+/-}$mice [217]. Recently, Ryu and colleagues showed that selectively reducing the interaction between mutant SHP2 and Gab1 in excitatory neurons reversed the physiological and behavioral deficits in a mouse model of NS [162]. Conditional mutant mice with higher spatial and temporal resolution will provide clues when, where, and which cell types are most suited for interventions.

Lastly, it should be noted that most of the RASopathy mechanism studies have used mice as a model system. Mouse models have many advantages and can be used to study neuropsychiatric disorders because the majority of neuropsychiatric drugs used in humans were shown to be, at least partially, effective in mouse models [218]. However, caution is still warranted. Nowadays, it has become relatively easy to model diseases in vitro using iPSC and several iPSC lines are available to study RASopathies, allowing for parallel and comparative analyses in vitro and in vivo.

\section{Abbreviations \\ Ascl1: Achaete scute-like 1; BLBP: Brain lipid binding protein; CFCS: Cardio- facio-cutaneous syndrome; CKO: Conditional knockout; CNS: Central nervous system; CS: Costello syndrome; ERK: Extracellular signal-regulated kinase; GABAergic: Gamma-aminobutyric acidergic; GAPs: GTPase activating proteins; GEFs: Guanine nucleotide exchange factors; GFAP: Glial fibrillary acidic protein; GNPs: Granule neuron progenitors; HCM: Hypertrophic cardiomyopathy; iPSCs: Induced pluripotent stem cells; JAK: Janus kinase; KRAS: Kirsten rat sarcoma viral oncogene homolog; MEK1/2: MAPK/ERK kinase 1/2; Neurog2: Neurogenin 2; NF1: Neurofibromatosis type 1; NRAS: Neuroblastoma RAS viral oncogene homolog; NS: Noonan syndrome; NSCs: Neural stem cells; NSML: Noonan syndrome with multiple lentigines; PI3K: Phosphatidylinositol 3-kinase; PTPN11: Protein tyrosine phosphatase non-receptor type 11; RTKs: Receptor tyrosine kinases; SHOC2: Soc-2 suppressor of clear homolog; SOS1: Son of sevenless homolog 1; STAT: Signal transducer and activator of transcription}

\section{Acknowledgements}

Authors thank Jae Yoon Hwang for proofreading the manuscript and all the members of laboratory of neurophysiology for their comments on the manuscript.

\section{Authors' contributions}

Y-SL and MK contributed to conception. MK and Y-SL reviewed the literatures and wrote the manuscript. MK generated figures and tables. Both authors read and approved the final manuscript.

\section{Funding}

This work was supported by the NRF-2016H1A2A1907206 grant to M.K. and the NRF-2019R1A2C1084232, NRF-2019R1A4A2001609 and NRF-

2017M3C7A1026959 grants to Y.-S.L.
Availability of data and materials

Not applicable

Ethics approval and consent to participate

Not applicable

\section{Consent for publication}

Not applicable

\section{Competing interests}

The authors declare that they have no competing interests.

\section{Author details}

'Department of Physiology, Seoul National University College of Medicine, 103 Daehak-ro, Jongro-gu, Seoul 03080, South Korea. ${ }^{2}$ Department of Biomedical Sciences, Seoul National University College of Medicine, Seoul 03080, Korea. ${ }^{3}$ Neuroscience Research Institute, Seoul National University College of Medicine, 103 Daehak-ro, Jongro-gu, Seoul 03080, South Korea.

Received: 23 July 2019 Accepted: 28 October 2019

Published online: 21 November 2019

\section{References}

1. Kolch W. Meaningful relationships: the regulation of the Ras/Raf/MEK/ERK pathway by protein interactions. Biochem J. 2000;351(Pt 2):289-305.

2. Boguski MS, McCormick F. Proteins regulating Ras and its relatives. Nature. 1993;366:643-54.

3. Ryu HH, Lee YS. Cell type-specific roles of RAS-MAPK signaling in learning and memory: Implications in neurodevelopmental disorders. Neurobiol Learn Mem. 2016;135:13-21.

4. Rauen KA. The RASopathies. Annu Rev Genomics Hum Genet. 2013;14:35569.

5. Innocenti M, Tenca P, Frittoli E, Faretta M, Tocchetti A, Di Fiore PP, Scita G. Mechanisms through which Sos-1 coordinates the activation of Ras and Rac. J Cell Biol. 2002;156:125-36.

6. Zhao L, Brinton RD. Vasopressin-induced cytoplasmic and nuclear calcium signaling in embryonic cortical astrocytes: dynamics of calcium and calcium-dependent kinase translocation. J Neurosci. 2003;23:4228-39.

7. Deak M, Clifton AD, Lucocq LM, Alessi DR. Mitogen- and stress-activated protein kinase-1 (MSK1) is directly activated by MAPK and SAPK2/p38, and may mediate activation of CREB. EMBO J. 1998;17:4426-41.

8. Shilyansky C, Lee YS, Silva AJ. Molecular and cellular mechanisms of learning disabilities: a focus on NF1. Annu Rev Neurosci. 2010:33:221-43.

9. Kim YE, Baek ST. Neurodevelopmental Aspects of RASopathies. Mol Cells. 2019;42:441-7.

10. Tidyman WE, Rauen KA. The RASopathies: developmental syndromes of Ras/ MAPK pathway dysregulation. Curr Opin Genet Dev. 2009:19:230-6.

11. Jindal GA, Goyal Y, Burdine RD, Rauen KA, Shvartsman SY. RASopathies: unraveling mechanisms with animal models. Dis Model Mech. 2015;8: 769-82.

12. Ferner RE, Huson SM, Thomas N, Moss C, Willshaw H, Evans DG, Upadhyaya M, Towers R, Gleeson M, Steiger C, et al. Guidelines for the diagnosis and management of individuals with neurofibromatosis 1. J Med Genet. 2007;44: $81-8$.

13. Rosman NP, Pearce J. The brain in multiple neurofibromatosis (von Recklinghausen's disease): a suggested neuropathological basis for the associated mental defect. Brain. 1967;90:829-38.

14. Listernick R, Charrow J, Greenwald MJ, Esterly NB. Optic gliomas in children with neurofibromatosis type 1. J Pediatr. 1989;114:788-92.

15. Krab LC, Aarsen FK, de Goede-Bolder A, Catsman-Berrevoets CE, Arts WF, Moll HA, Elgersma Y. Impact of neurofibromatosis type 1 on school performance. J Child Neurol. 2008;23:1002-10.

16. Shilyansky C, Karlsgodt KH, Cummings DM, Sidiropoulou K, Hardt M, James AS, Ehninger D, Bearden CE, Poirazi P, Jentsch JD, et al. Neurofibromin regulates corticostriatal inhibitory networks during working memory performance. Proc Natl Acad Sci U S A. 2010;107:13141-6.

17. Cichowski K, Jacks T. NF1 tumor suppressor gene function: narrowing the GAP. Cell. 2001;104:593-604.

18. Zhu Y, Parada LF. Neurofibromin, a tumor suppressor in the nervous system. Exp Cell Res. 2001;264:19-28. 
19. Brems H, Legius E. Legius syndrome, an Update. Molecular pathology of mutations in SPRED1. Keio J Med. 2013;62:107-12.

20. Williams VC, Lucas J, Babcock MA, Gutmann DH, Korf B, Maria BL. Neurofibromatosis type 1 revisited. Pediatrics. 2009;123:124-33.

21. Tartaglia M, Kalidas K, Shaw A, Song X, Musat DL, van der Burgt I, Brunner HG, Bertola DR, Crosby A, lon A, et al. PTPN11 mutations in Noonan syndrome: molecular spectrum, genotype-phenotype correlation, and phenotypic heterogeneity. Am J Hum Genet. 2002;70:1555-63.

22. Razzaque MA, Nishizawa T, Komoike Y, Yagi H, Furutani M, Amo R, Kamisago M, Momma K, Katayama H, Nakagawa M, et al. Germline gain-of-function mutations in RAF1 cause Noonan syndrome. Nat Genet. 2007;39:1013-7.

23. Pandit B, Sarkozy A, Pennacchio LA, Carta C, Oishi K, Martinelli S, Pogna EA, Schackwitz W, Ustaszewska A, Landstrom A, et al. Gain-of-function RAF1 mutations cause Noonan and LEOPARD syndromes with hypertrophic cardiomyopathy. Nat Genet. 2007;39:1007-12.

24. Tartaglia M, Pennacchio LA, Zhao C, Yadav KK, Fodale V, Sarkozy A, Pandit B, Oishi K, Martinelli S, Schackwitz W, et al. Gain-of-function SOS1 mutations cause a distinctive form of Noonan syndrome. Nat Genet. 2007;39:75-9.

25. Schubbert S, Zenker M, Rowe SL, Boll S, Klein C, Bollag G, van der Burgt I, Musante L, Kalscheuer V, Wehner LE, et al. Germline KRAS mutations cause Noonan syndrome. Nat Genet. 2006;38:331-6.

26. Carta C, Pantaleoni F, Bocchinfuso G, Stella L, Vasta I, Sarkozy A, Digilio C, Palleschi A, Pizzuti A, Grammatico P, et al. Germline missense mutations affecting KRAS Isoform B are associated with a severe Noonan syndrome phenotype. Am J Hum Genet. 2006;79:129-35.

27. Nava C, Hanna N, Michot C, Pereira S, Pouvreau N, Niihori T, Aoki Y, Matsubara Y, Arveiler B, Lacombe D, et al. Cardio-facio-cutaneous and Noonan syndromes due to mutations in the RAS/MAPK signalling pathway: genotype-phenotype relationships and overlap with Costello syndrome. J Med Genet. 2007:44:763-71.

28. Peiris A, Ball MJ. Chiari (type 1) malformation and syringomyelia in a patient with Noonan's syndrome. J Neurol Neurosurg Psychiatry. 1982;45:753-4.

29. Kobayashi I, Aikawa T, Takemiya T, Maruyama S, Takano K. Noonan's syndrome with syringomyelia. Jpn J Psychiatry Neurol. 1986;40:101-4.

30. Gorke W. Cerebral defects in Noonan's syndrome (author's transl). Klin Padiatr. 1980;192:577-81.

31. Noonan JA. Hypertelorism with Turner phenotype. A new syndrome with associated congenital heart disease. Am J Dis Child. 1968;116:373-80.

32. Raman Unnithan R, Bahuleyan CG, Matnew Roy VC. Noonan syndrome. J Assoc Physicians India. 1985;33:177-9.

33. Saito Y, Sasaki M, Hanaoka S, Sugai K, Hashimoto T. A case of Noonan syndrome with cortical dysplasia. Pediatr Neurol. 1997;17:266-9.

34. Cesarini L, Alfieri P, Pantaleoni F, Vasta I, Cerutti M, Petrangeli V, Mariotti P, Leoni C, Ricci D, Vicari S, et al. Cognitive profile of disorders associated with dysregulation of the RAS/MAPK signaling cascade. Am J Med Genet A. 2009; 149A(2):140-6.

35. Pierpont El, Pierpont ME, Mendelsohn NJ, Roberts AE, Tworog-Dube E, Seidenberg MS. Genotype differences in cognitive functioning in Noonan syndrome. Genes Brain Behav. 2009;8:275-82.

36. Aoki Y, Niihori T, Banjo T, Okamoto N, Mizuno S, Kurosawa K, Ogata T, Takada F, Yano M, Ando T, et al. Gain-of-function mutations in RIT1 cause Noonan syndrome, a RAS/MAPK pathway syndrome. Am J Hum Genet. 2013;93:173-80.

37. Lee DA, Portnoy S, Hill P, Gillberg C, Patton MA. Psychological profile of children with Noonan syndrome. Dev Med Child Neurol. 2005;47:35-8.

38. Razzaque MA, Komoike Y, Nishizawa T, Inai K, Furutani M, Higashinakagawa T, Matsuoka R. Characterization of a novel KRAS mutation identified in Noonan syndrome. Am J Med Genet A. 2012;158A(3):524-32.

39. Roberts AE, Allanson JE, Tartaglia M, Gelb BD. Noonan syndrome. Lancet. 2013;381:333-42.

40. van der Burgt I, Thoonen G, Roosenboom N, Assman-Hulsmans C, Gabreels F, Otten B, Brunner HG. Patterns of cognitive functioning in school-aged children with Noonan syndrome associated with variability in phenotypic expression. J Pediatr. 1999;135:707-13.

41. Niihori T, Aoki Y, Narumi Y, Neri G, Cave H, Verloes A, Okamoto N, Hennekam RC, Gillessen-Kaesbach G, Wieczorek D, et al. Germline KRAS and BRAF mutations in cardio-facio-cutaneous syndrome. Nat Genet. 2006;38:294-6.

42. Rodriguez-Viciana P, Tetsu O, Tidyman WE, Estep AL, Conger BA, Cruz MS, McCormick F, Rauen KA. Germline mutations in genes within the MAPK pathway cause cardio-facio-cutaneous syndrome. Science. 2006;311: 1287-90.
43. Narumi Y, Aoki Y, Niihori T, Neri G, Cave H, Verloes A, Nava C, Kavamura Ml, Okamoto N, Kurosawa K, et al. Molecular and clinical characterization of cardio-facio-cutaneous (CFC) syndrome: overlapping clinical manifestations with Costello syndrome. Am J Med Genet A. 2007;143a:799-807.

44. Reynolds JF, Neri G, Herrmann JP, Blumberg B, Coldwell JG, Miles PV, Opitz JM. New multiple congenital anomalies/mental retardation syndrome with cardio-facio-cutaneous involvement--the CFC syndrome. Am J Med Genet. 1986;25:413-27.

45. Neri G, Sabatino G, Bertini E, Genuardi M. The CFC syndrome--report of the first two cases outside the United States. Am J Med Genet. 1987;27:767-71.

46. Chrzanowska K, Fryns JP, Van den Berghe H. Cardio-facio-cutaneous (CFC) syndrome: report of a new patient. Am J Med Genet. 1989;33:471-3.

47. Ades LC, Sillence DO, Rogers M. Cardiofaciocutaneous syndrome. Clin Dysmorphol. 1992;1:145-50.

48. Young TL, Ziylan S, Schaffer DB. The ophthalmologic manifestations of the cardio-facio-cutaneous syndrome. J Pediatr Ophthalmol Strabismus. 1993;30: 48-52.

49. Krajewska-Walasek M, Chrzanowska K, Jastrzbska M. The cardio-faciocutaneous (CFC) syndrome--two possible new cases and review of the literature. Clin Dysmorphol. 1996;5:65-72.

50. Yoon G, Rosenberg J, Blaser S, Rauen KA. Neurological complications of cardio-facio-cutaneous syndrome. Dev Med Child Neurol. 2007;49:894-9.

51. Somer M, Peippo M, Aalto-Korte K, Ritvanen A, Niemi KM. Cardio-faciocutaneous syndrome: three additional cases and review of the literature. Am J Med Genet. 1992;44:691-5.

52. Grebe TA, Clericuzio C. Neurologic and gastrointestinal dysfunction in cardio-facio-cutaneous syndrome: identification of a severe phenotype. Am J Med Genet. 2000;95:135-43.

53. Manci EA, Martinez JE, Horenstein MG, Gardner TM, Ahmed A, Mancao MC, Gremse DA, Gardner DM, Nimityongskul P, Maertens P, et al. Cardiofaciocutaneous syndrome (CFC) with congenital peripheral neuropathy and nonorganic malnutrition: an autopsy study. Am J Med Genet A. 2005;137:1-8.

54. Baraitser M, Patton MA. A Noonan-like short stature syndrome with sparse hair. J Med Genet. 1986;23:161-4.

55. Armour CM, Allanson JE. Further delineation of cardio-facio-cutaneous syndrome: clinical features of 38 individuals with proven mutations. J Med Genet. 2008:45:249-54.

56. Papadopoulou E, Sifakis S, Sol-Church K, Klein-Zighelboim E, Stabley DL, Raissaki M, Gripp KW, Kalmanti M. CNS imaging is a key diagnostic tool in the evaluation of patients with CFC syndrome: two cases and literature review. Am J Med Genet A. 2011;155a:605-11.

57. Wieczorek D, Majewski F, Gillessen-Kaesbach G. Cardio-facio-cutaneous (CFC) syndrome--a distinct entity? Report of three patients demonstrating the diagnostic difficulties in delineation of CFC syndrome. Clin Genet. 1997; 52:37-46.

58. Roberts A, Allanson J, Jadico SK, Kavamura MI, Noonan J, Opitz JM, Young T, Neri G. The cardiofaciocutaneous syndrome. J Med Genet. 2006;43:833-42.

59. Schulz AL, Albrecht B, Arici C, van der Burgt I, Buske A, Gillessen-Kaesbach G, Heller R, Horn D, Hubner CA, Korenke GC, et al. Mutation and phenotypic spectrum in patients with cardio-facio-cutaneous and Costello syndrome. Clin Genet. 2008;73:62-70.

60. Aoki Y, Niihori T, Kawame H, Kurosawa K, Ohashi H, Tanaka Y, Filocamo M, Kato K, Suzuki Y, Kure S, et al. Germline mutations in HRAS proto-oncogene cause Costello syndrome. Nat Genet. 2005:37:1038-40.

61. Kerr B, Delrue MA, Sigaudy S, Perveen R, Marche M, Burgelin I, Stef M, Tang B, Eden OB, O'Sullivan J, et al. Genotype-phenotype correlation in Costello syndrome: HRAS mutation analysis in 43 cases. J Med Genet. 2006;43:401-5.

62. Estep AL, Tidyman WE, Teitell MA, Cotter PD, Rauen KA. HRAS mutations in Costello syndrome: detection of constitutional activating mutations in codon 12 and 13 and loss of wild-type allele in malignancy. Am J Med Genet A. 2006;140:8-16.

63. Zenker M, Lehmann K, Schulz AL, Barth H, Hansmann D, Koenig R, Korinthenberg R, Kreiss-Nachtsheim M, Meinecke P, Morlot S, et al. Expansion of the genotypic and phenotypic spectrum in patients with KRAS germline mutations. J Med Genet. 2007:44:131-5.

64. Der Kaloustian VM, Moroz B, McIntosh N, Watters AK, Blaichman S. Costello syndrome. Am J Med Genet. 1991:41:69-73.

65. Zampino G, Mastroiacovo P, Ricci R, Zollino M, Segni G, Martini-Neri ME, Neri G. Costello syndrome: further clinical delineation, natural history, genetic definition, and nosology. Am J Med Genet. 1993;47:176-83. 
66. Gripp KW, Scott Cl Jr, Nicholson L, Figueroa TE. Second case of bladder carcinoma in a patient with Costello syndrome. Am J Med Genet. 2000;90: 256-9.

67. Gripp KW, Scott CI Jr, Nicholson L, McDonald-McGinn DM, Ozeran JD, Jones MC, Lin AE, Zackai EH. Five additional Costello syndrome patients with rhabdomyosarcoma: proposal for a tumor screening protocol. Am J Med Genet. 2002;108:80-7.

68. Fryns JP, Vogels A, Haegeman J, Eggermont E, van den Berghe H. Costello syndrome: a postnatal growth retardation syndrome with distinct phenotype. Genet Couns. 1994;5:337-43.

69. Johnson JP, Golabi M, Norton ME, Rosenblatt RM, Feldman GM, Yang SP, Hall BD, Fries MH, Carey JC. Costello syndrome: phenotype, natural history, differential diagnosis, and possible cause. J Pediatr. 1998;133:441-8.

70. Kerr B, Eden OB, Dandamudi R, Shannon N, Quarrell O, Emmerson A, Ladusans E, Gerrard M, Donnai D. Costello syndrome: two cases with embryonal rhabdomyosarcoma. J Med Genet. 1998;35:1036-9.

71. van Eeghen AM, van Gelderen I, Hennekam RC. Costello syndrome: report and review. Am J Med Genet. 1999;82:187-93.

72. Say B, Gucsavas M, Morgan H, York C. The Costello syndrome. Am J Med Genet. 1993;47:163-5.

73. Delrue MA, Chateil JF, Arveiler B, Lacombe D. Costello syndrome and neurological abnormalities. Am J Med Genet. 2003;123a:301-5.

74. Okamoto N, Chiyo H, Imai K, Otani K, Futagi Y. A Japanese patient with the Costello syndrome. Hum Genet. 1994;93:605-6.

75. Lakkis MM, Golden JA, O'Shea KS, Epstein JA. Neurofibromin deficiency in mice causes exencephaly and is a modifier for Splotch neural tube defects. Dev Biol. 1999;212:80-92.

76. Brannan Cl, Perkins AS, Vogel KS, Ratner N, Nordlund ML, Reid SW, Buchberg AM, Jenkins NA, Parada LF, Copeland NG. Targeted disruption of the neurofibromatosis type-1 gene leads to developmental abnormalities in heart and various neural crest-derived tissues. Genes Dev. 1994;8:1019-29.

77. Jacks T, Shih TS, Schmitt EM, Bronson RT, Bernards A, Weinberg RA. Tumour predisposition in mice heterozygous for a targeted mutation in Nf1. Nat Genet. 1994;7:353-61.

78. Gutmann DH, Loehr A, Zhang Y, Kim J, Henkemeyer M, Cashen A. Haploinsufficiency for the neurofibromatosis 1 (NF1) tumor suppressor results in increased astrocyte proliferation. Oncogene. 1999;18:4450-9.

79. Rizvi TA, Akunuru S, de Courten-Myers G, Switzer RC 3rd, Nordlund ML, Ratner N. Region-specific astrogliosis in brains of mice heterozygous for mutations in the neurofibromatosis type 1 (Nf1) tumor suppressor. Brain Res. 1999;816:111-23.

80. Costa RM, Federov NB, Kogan JH, Murphy GG, Stern J, Ohno M, Kucherlapati $R$, Jacks T, Silva AJ. Mechanism for the learning deficits in a mouse model of neurofibromatosis type 1. Nature. 2002;415:526-30.

81. Silva AJ, Frankland PW, Marowitz Z, Friedman E, Laszlo GS, Cioffi D, Jacks T, Bourtchuladze R. A mouse model for the learning and memory deficits associated with neurofibromatosis type I. Nat Genet. 1997;15:281-4.

82. Costa RM, Yang T, Huynh DP, Pulst SM, Viskochil DH, Silva AJ, Brannan Cl. Learning deficits, but normal development and tumor predisposition, in mice lacking exon 23a of Nf1. Nat Genet. 2001;27:399-405.

83. Zhu Y, Romero Ml, Ghosh P, Ye Z, Charnay P, Rushing EJ, Marth JD, Parada LF. Ablation of NF1 function in neurons induces abnormal development of cerebral cortex and reactive gliosis in the brain. Genes Dev. 2001;15:859-76.

84. Cui Y, Costa RM, Murphy GG, Elgersma Y, Zhu Y, Gutmann DH, Parada LF, Mody I, Silva AJ. Neurofibromin regulation of ERK signaling modulates GABA release and learning. Cell. 2008;135:549-60.

85. Wang Y, Kim E, Wang X, Novitch BG, Yoshikawa K, Chang LS, Zhu Y. ERK inhibition rescues defects in fate specification of Nf1-deficient neural progenitors and brain abnormalities. Cell. 2012;150:816-30.

86. Zhu Y, Harada T, Liu L, Lush ME, Guignard F, Harada C, Burns DK, Bajenaru ML, Gutmann DH, Parada LF. Inactivation of NF1 in CNS causes increased glial progenitor proliferation and optic glioma formation. Development. 2005;132:5577-88.

87. Lush ME, Li Y, Kwon CH, Chen J, Parada LF. Neurofibromin is required for barrel formation in the mouse somatosensory cortex. J Neurosci. 2008;28:1580-7.

88. Sanchez-Ortiz E, Cho W, Nazarenko I, Mo W, Chen J, Parada LF. NF1 regulation of RAS/ERK signaling is required for appropriate granule neuron progenitor expansion and migration in cerebellar development. Genes Dev. 2014;28:2407-20.

89. Hegedus B, Dasgupta B, Shin JE, Emnett RJ, Hart-Mahon EK, Elghazi L, Bernal-Mizrachi E, Gutmann DH. Neurofibromatosis-1 regulates neuronal and glial cell differentiation from neuroglial progenitors in vivo by both cAMP- and Ras-dependent mechanisms. Cell Stem Cell. 2007;1:443-57.

90. Sun GJ, Zhou Y, Ito S, Bonaguidi MA, Stein-O'Brien G, Kawasaki NK, Modak N, Zhu Y, Ming GL, Song H. Latent tri-lineage potential of adult hippocampal neural stem cells revealed by Nf1 inactivation. Nat Neurosci. 2015;18:1722-4.

91. Li Y, Li Y, McKay RM, Riethmacher D, Parada LF. Neurofibromin modulates adult hippocampal neurogenesis and behavioral effects of antidepressants. J Neurosci. 2012;32:3529-39.

92. Ke Y, Zhang EE, Hagihara K, Wu D, Pang Y, Klein R, Curran T, Ranscht B, Feng GS. Deletion of Shp2 in the brain leads to defective proliferation and differentiation in neural stem cells and early postnatal lethality. Mol Cell Biol. 2007;27:6706-17.

93. Zhu Y, Park J, Hu X, Zheng K, Li H, Cao Q, Feng GS, Qiu M. Control of oligodendrocyte generation and proliferation by Shp2 protein tyrosine phosphatase. Glia. 2010;58:1407-14.

94. Ehrman LA, Nardini D, Ehrman S, Rizvi TA, Gulick J, Krenz M, Dasgupta B, Robbins J, Ratner N, Nakafuku M, et al. The protein tyrosine phosphatase Shp2 is required for the generation of oligodendrocyte progenitor cells and myelination in the mouse telencephalon. J Neurosci. 2014;34:3767-78.

95. Zheng H, Yu WM, Waclaw RR, Kontaridis MI, Neel BG, Qu CK. Gain-of-function mutations in the gene encoding the tyrosine phosphatase SHP2 induce hydrocephalus in a catalytically dependent manner. Sci Signal. 2018;11:eaao1591.

96. Gauthier AS, Furstoss O, Araki T, Chan R, Neel BG, Kaplan DR, Miller FD. Control of CNS cell-fate decisions by SHP-2 and its dysregulation in Noonan syndrome. Neuron. 2007;54:245-62.

97. Lee YS, Ehninger D, Zhou M, Oh JY, Kang M, Kwak C, Ryu HH, Butz D, Araki T, Cai $Y$, et al. Mechanism and treatment for learning and memory deficits in mouse models of Noonan syndrome. Nat Neurosci. 2014;17:1736-43.

98. Araki T, Mohi MG, Ismat FA, Bronson RT, Williams IR, Kutok JL, Yang W, Pao LI, Gilliland DG, Epstein JA, et al. Mouse model of Noonan syndrome reveals cell type- and gene dosage-dependent effects of Ptpn11 mutation. Nat Med. 2004;10:849-57.

99. Papale A, d'Isa R, Menna E, Cerovic M, Solari N, Hardingham N, Cambiaghi M, Cursi M, Barbacid M, Leocani L, et al. Severe Intellectual Disability and Enhanced Gamma-Aminobutyric Acidergic Synaptogenesis in a Novel Model of Rare RASopathies. Biol Psychiatry. 2017:81:179-92.

100. Schreiber J, Grimbergen LA, Overwater I, Vaart TV, Stedehouder J, Schuhmacher AJ, Guerra C, Kushner SA, Jaarsma D, Elgersma Y. Mechanisms underlying cognitive deficits in a mouse model for Costello Syndrome are distinct from other RASopathy mouse models. Sci Rep. 2017;7:1256.

101. Kushner SA, Elgersma Y, Murphy GG, Jaarsma D, van Woerden GM, Hojjati MR, Cui Y, LeBoutillier JC, Marrone DF, Choi ES, et al. Modulation of presynaptic plasticity and learning by the $\mathrm{H}$-ras/extracellular signal-regulated kinase/synapsin I signaling pathway. J Neurosci. 2005;25:9721-34.

102. Pfeiffer V, Gotz R, Xiang C, Camarero G, Braun A, Zhang Y, Blum R, Heinsen $H$, Nieswandt B, Rapp UR. Ablation of BRaf impairs neuronal differentiation in the postnatal hippocampus and cerebellum. PLoS One. 2013;8:e58259.

103. Galabova-Kovacs G, Catalanotti F, Matzen D, Reyes GX, Zezula J, Herbst R, Silva A, Walter I, Baccarini M. Essential role of B-Raf in oligodendrocyte maturation and myelination during postnatal central nervous system development. J Cell Biol. 2008;180:947-55.

104. Urosevic J, Sauzeau V, Soto-Montenegro ML, Reig S, Desco M, Wright EM, Canamero M, Mulero F, Ortega S, Bustelo XR, et al. Constitutive activation of B-Raf in the mouse germ line provides a model for human cardio-faciocutaneous syndrome. Proc Natl Acad Sci U S A. 2011;108:5015-20.

105. Pfeiffer V, Gotz R, Camarero G, Heinsen H, Blum R, Rapp UR. Impaired neuronal maturation of hippocampal neural progenitor cells in mice lacking CRAF. PLoS One. 2018;13:e0192067.

106. Preiss T, Hentze MW. From factors to mechanisms: translation and translational control in eukaryotes. Curr Opin Genet Dev. 1999;9:515-21.

107. Holter MC, Hewitt LT, Koebele SV, Judd JM, Xing L, Bimonte-Nelson HA, Conrad CD, Araki T, Neel BG, Snider WD, et al. The Noonan Syndrome-linked Raf1L613V mutation drives increased glial number in the mouse cortex and enhanced learning. PLoS Genet. 2019;15:e1008108.

108. Aoidi R, Houde N, Landry-Truchon K, Holter M, Jacquet K, Charron L, Krishnaswami SR, Yu BD, Rauen KA, Bisson N, et al. Mek1(Y130C) mice recapitulate aspects of human cardio-facio-cutaneous syndrome. Dis Model Mech. 2018;11:dmm031278.

109. Li X, Newbern JM, Wu Y, Morgan-Smith M, Zhong J, Charron J, Snider WD. MEK Is a Key Regulator of Gliogenesis in the Developing Brain. Neuron. 2012;75:1035-50. 
110. Ivanova T, Karolczak M, Beyer C. Estrogen stimulates the mitogen-activated protein kinase pathway in midbrain astroglia. Brain Res. 2001;889:264-9.

111. Campos LS, Leone DP, Relvas JB, Brakebusch C, Fassler R, Suter U. ffrenchConstant C. Beta1 integrins activate a MAPK signalling pathway in neural stem cells that contributes to their maintenance. Development. 2004;131: 3433-44.

112. Bonni A, Brunet A, West AE, Datta SR, Takasu MA, Greenberg ME. Cell survival promoted by the Ras-MAPK signaling pathway by transcriptiondependent and -independent mechanisms. Science. 1999;286:1358-62.

113. Xia Z, Dickens M, Raingeaud J, Davis RJ, Greenberg ME. Opposing effects of ERK and JNK-p38 MAP kinases on apoptosis. Science. 1995;270:1326-31.

114. Michaelidis TM, Sendtner M, Cooper JD, Airaksinen MS, Holtmann B, Meyer $\mathrm{M}$, Thoenen $\mathrm{H}$. Inactivation of bcl-2 results in progressive degeneration of motoneurons, sympathetic and sensory neurons during early postnatal development. Neuron. 1996:17:75-89.

115. Krasilnikov M, Ivanov VN, Dong J, Ronai Z. ERK and PI3K negatively regulate STAT-transcriptional activities in human melanoma cells: implications towards sensitization to apoptosis. Oncogene. 2003;22:4092-101.

116. Kulich SM, Chu CT. Sustained extracellular signal-regulated kinase activation by 6-hydroxydopamine: implications for Parkinson's disease. J Neurochem. 2001;77:1058-66.

117. Russo C, Dolcini V, Salis S, Venezia V, Violani E, Carlo P, Zambrano N, Russo $T$, Schettini G. Signal transduction through tyrosine-phosphorylated carboxy-terminal fragments of APP via an enhanced interaction with Shc/ Grb2 adaptor proteins in reactive astrocytes of Alzheimer's disease brain. Ann N Y Acad Sci. 2002;973:323-33.

118. Pucilowska J, Puzerey PA, Karlo JC, Galan RF, Landreth GE. Disrupted ERK signaling during cortical development leads to abnormal progenitor proliferation, neuronal and network excitability and behavior, modeling human neuro-cardio-facial-cutaneous and related syndromes. J Neurosci. 2012;32:8663-77

119. Menard C, Hein P, Paquin A, Savelson A, Yang XM, Lederfein D, BarnabeHeider F, Mir AA, Sterneck E, Peterson AC, et al. An essential role for a MEKC/EBP pathway during growth factor-regulated cortical neurogenesis. Neuron. 2002;36:597-610

120. Song MR, Ghosh A. FGF2-induced chromatin remodeling regulates CNTFmediated gene expression and astrocyte differentiation. Nat Neurosci. 2004; 7:229-35.

121. Morrow T, Song MR, Ghosh A. Sequential specification of neurons and glia by developmentally regulated extracellular factors. Development. 2001;128: 3585-94.

122. Bajetto A, Barbero S, Bonavia R, Piccioli P, Pirani P, Florio T, Schettini G. Stromal cell-derived factor-1alpha induces astrocyte proliferation through the activation of extracellular signal-regulated kinases $1 / 2$ pathway. J Neurochem. 2001;77:1226-36.

123. Baron W, Metz B, Bansal R, Hoekstra D, de Vries H. PDGF and FGF-2 signaling in oligodendrocyte progenitor cells: regulation of proliferation and differentiation by multiple intracellular signaling pathways. Mol Cell Neurosci. 2000;15:314-29.

124. Guardiola-Diaz HM, Ishii A, Bansal R. Erk1/2 MAPK and mTOR signaling sequentially regulates progression through distinct stages of oligodendrocyte differentiation. Glia. 2012;60:476-86.

125. Fyffe-Maricich SL, Karlo JC, Landreth GE, Miller RH. The ERK2 mitogenactivated protein kinase regulates the timing of oligodendrocyte differentiation. J Neurosci. 2011;31:843-50.

126. Xiao J, Ferner AH, Wong AW, Denham M, Kilpatrick TJ, Murray SS. Extracellular signal-regulated kinase $1 / 2$ signaling promotes oligodendrocyte myelination in vitro. J Neurochem. 2012;122:1167-80.

127. Suo N, Guo YE, He B. Gu H, Xie X. Glia: Inhibition of MAPK/ERK pathway promotes oligodendrocytes generation and recovery of demyelinating diseases; 2019

128. Fressinaud C, Vallat JM, Labourdette G. Basic fibroblast growth factor downregulates myelin basic protein gene expression and alters myelin compaction of mature oligodendrocytes in vitro. J Neurosci Res. 1995;40:285-93.

129. Bansal R, Pfeiffer SE. FGF-2 converts mature oligodendrocytes to a novel phenotype. J Neurosci Res. 1997;50:215-28.

130. Canoll PD, Kraemer R, Teng KK, Marchionni MA, Salzer JL. GGF/neuregulin induces a phenotypic reversion of oligodendrocytes. Mol Cell Neurosci. 1999;13:79-94.

131. Casarosa S, Fode C, Guillemot F. Mash1 regulates neurogenesis in the ventral telencephalon. Development. 1999;126:525-34.
132. Britz O, Mattar P, Nguyen L, Langevin LM, Zimmer C, Alam S, Guillemot F, Schuurmans C. A role for proneural genes in the maturation of cortical progenitor cells. Cereb Cortex. 2006;16:1138-51.

133. Parras CM, Hunt C, Sugimori M, Nakafuku M, Rowitch D, Guillemot F. The proneural gene Mash1 specifies an early population of telencephalic oligodendrocytes. J Neurosci. 2007;27:4233-42.

134. Li S, Mattar P, Dixit R, Lawn SO, Wilkinson G, Kinch C, Eisenstat D, Kurrasch DM, Chan JA, Schuurmans C. RAS/ERK signaling controls proneural genetic programs in cortical development and gliomagenesis. J Neurosci. 2014;34: 2169-90.

135. Vivanco I, Sawyers CL. The phosphatidylinositol 3-Kinase AKT pathway in human cancer. Nat Rev Cancer. 2002;2:489-501.

136. Castellano E, Downward J. Role of RAS in the regulation of PI 3-kinase. Curr Top Microbiol Immunol. 2010;346:143-69.

137. Downward J. Targeting RAS signalling pathways in cancer therapy. Nat Rev Cancer. 2003;3:11-22.

138. Mendoza MC, Er EE, Blenis J. The Ras-ERK and PI3K-mTOR pathways: crosstalk and compensation. Trends Biochem Sci. 2011;36:320-8.

139. Kim Jl, Lee HR, Sim SE, Baek J, Yu NK, Choi JH, Ko HG, Lee YS, Park SW, Kwak $C$, et al. PI3Kgamma is required for NMDA receptor-dependent long-term depression and behavioral flexibility. Nat Neurosci. 2011;14:1447-54.

140. Choi JH, Park P, Baek GC, Sim SE, Kang SJ, Lee Y, Ahn SH, Lim CS, Lee YS, Collingridge $\mathrm{GL}$, et al. Effects of PI3Kgamma overexpression in the hippocampus on synaptic plasticity and spatial learning. Mol Brain. 2014;7: 78.

141. Rawlings JS, Rosler KM, Harrison DA. The JAKJSTAT signaling pathway. J Cell Sci. 2004;117:1281-3.

142. Nicolas CS, Peineau S, Amici M, Csaba Z, Fafouri A, Javalet C, Collett VJ, Hildebrandt L, Seaton G, Choi SL, et al. The Jak/STAT pathway is involved in synaptic plasticity. Neuron. 2012;73:374-90.

143. Krab LC, Goorden SM, Elgersma Y. Oncogenes on my mind: ERK and MTOR signaling in cognitive diseases. Trends Genet. 2008;24:498-510.

144. Bentires-Alj M, Kontaridis MI, Neel BG. Stops along the RAS pathway in human genetic disease. Nat Med. 2006;12:283-5.

145. Cawthon RM, Weiss R, Xu GF, Viskochil D, Culver M, Stevens J, Robertson M, Dunn D, Gesteland R, O'Connell P, et al. A major segment of the neurofibromatosis type 1 gene: cDNA sequence, genomic structure, and point mutations. Cell. 1990;62:193-201.

146. Martin GA, Viskochil D, Bollag G, McCabe PC, Crosier WJ, Haubruck H, Conroy L, Clark R, O'Connell P, Cawthon RM, et al. The GAP-related domain of the neurofibromatosis type 1 gene product interacts with ras p21. Cell. 1990;63:843-9.

147. Gutmann DH, Aylsworth A, Carey JC, Korf B, Marks J, Pyeritz RE, Rubenstein A, Viskochil D. The diagnostic evaluation and multidisciplinary management of neurofibromatosis 1 and neurofibromatosis 2. Jama. 1997;278:51-7.

148. Listernick R, Charrow J, Gutmann DH. Intracranial gliomas in neurofibromatosis type 1. Am J Med Genet. 1999:89:38-44.

149. Nordlund ML, Rizvi TA, Brannan Cl, Ratner N. Neurofibromin expression and astrogliosis in neurofibromatosis (type 1) brains. J Neuropathol Exp Neurol. 1995:54:588-600.

150. Moore BD 3rd, Slopis JM, Jackson EF, De Winter AE, Leeds NE. Brain volume in children with neurofibromatosis type 1: relation to neuropsychological status. Neurology. 2000;54:914-20.

151. Pride N, Payne JM, Webster R, Shores EA, Rae C, North KN. Corpus callosum morphology and its relationship to cognitive function in neurofibromatosis type 1. J Child Neurol. 2010;25:834-41.

152. Costa RM, Silva AJ. Molecular and cellular mechanisms underlying the cognitive deficits associated with neurofibromatosis 1. J Child Neurol. 2002; 17:622-6 discussion 7-9, 46-51.

153. Li W, Cui Y, Kushner SA, Brown RA, Jentsch JD, Frankland PW, Cannon TD, Silva AJ. The HMG-CoA reductase inhibitor lovastatin reverses the learning and attention deficits in a mouse model of neurofibromatosis type 1. Curr Biol. 2005;15:1961-7

154. Acosta MT. Challenges of cognitive research in neurofibromatosis type 1. Lancet Neurol. 2013;12:1040-1.

155. Rabchevsky AG, Weinitz JM, Coulpier M, Fages C, Tinel M, Junier MP. A role for transforming growth factor alpha as an inducer of astrogliosis. J Neurosci. 1998;18:10541-52.

156. Zhuo L, Theis M, Alvarez-Maya I, Brenner M, Willecke K, Messing A. hGFAPcre transgenic mice for manipulation of glial and neuronal function in vivo. Genesis. 2001;31:85-94. 
157. Bennett MR, Rizvi TA, Karyala S, McKinnon RD, Ratner N. Aberrant growth and differentiation of oligodendrocyte progenitors in neurofibromatosis type 1 mutants. J Neurosci. 2003;23:7207-17.

158. Kim HA, Ling B, Ratner N. Nf1-deficient mouse Schwann cells are angiogenic and invasive and can be induced to hyperproliferate: reversion of some phenotypes by an inhibitor of farnesyl protein transferase. Mol Cell Biol. 1997;17:862-72.

159. Dasgupta B, Gutmann DH. Neurofibromin regulates neural stem cell proliferation, survival, and astroglial differentiation in vitro and in vivo. J Neurosci. 2005;25:5584-94.

160. Lee DY, Yeh TH, Emnett RJ, White CR, Gutmann DH. Neurofibromatosis-1 regulates neuroglial progenitor proliferation and glial differentiation in a brain region-specific manner. Genes Dev. 2010;24:2317-29.

161. Zhou Q, Anderson DJ. The bHLH transcription factors OLIG2 and OLIG1 couple neuronal and glial subtype specification. Cell. 2002;109:61-73.

162. Ryu HH, Kim T, Kim JW, Kang M, Park P, Kim YG, Kim H, Ha J, Choi JE, Lee J, et al. Excitatory neuron-specific SHP2-ERK signaling network regulates synaptic plasticity and memory. Sci Signal. 2019;12:eaau5755.

163. Ryu HH, Kang M, Park J, Park SH, Lee YS. Enriched expression of NF1 in inhibitory neurons in both mouse and human brain. Mol Brain. 2019;12:60.

164. Tartaglia M, Gelb BD. Noonan syndrome and related disorders: genetics and pathogenesis. Annu Rev Genomics Hum Genet. 2005;6:45-68.

165. Romano AA, Allanson JE, Dahlgren J, Gelb BD, Hall B, Pierpont ME, Roberts AE, Robinson W, Takemoto CM, Noonan JA. Noonan syndrome: clinical features, diagnosis, and management guidelines. Pediatrics. 2010;126:746-59.

166. Chen PC, Yin J, Yu HW, Yuan T, Fernandez M, Yung CK, Trinh QM, Peltekova VD, Reid JG, Tworog-Dube E, et al. Next-generation sequencing identifies rare variants associated with Noonan syndrome. Proc Natl Acad Sci U S A. 2014;111:11473-8.

167. Tartaglia M, Mehler EL, Goldberg R, Zampino G, Brunner HG, Kremer H, van der Burgt I, Crosby AH, Ion A, Jeffery S, et al. Mutations in PTPN11, encoding the protein tyrosine phosphatase SHP-2, cause Noonan syndrome. Nat Genet. 2001;29:465-8.

168. Sarkozy A, Digilio MC, Dallapiccola B. Leopard syndrome. Orphanet J Rare Dis. 2008:3:13.

169. Chen PC, Wakimoto H, Conner D, Araki T, Yuan T, Roberts A, Seidman C, Bronson R, Neel B, Seidman JG, et al. Activation of multiple signaling pathways causes developmental defects in mice with a Noonan syndromeassociated Sos1 mutation. J Clin Invest. 2010;120:4353-65.

170. Nakamura T, Gulick J, Pratt R, Robbins J. Noonan syndrome is associated with enhanced pERK activity, the repression of which can prevent craniofacial malformations. Proc Natl Acad Sci U S A. 2009;106:15436-41.

171. Hernandez-Porras I, Fabbiano S, Schuhmacher AJ, Aicher A, Canamero M, Camara JA, Cusso L, Desco M, Heeschen C, Mulero F, et al. K-RasV14I recapitulates Noonan syndrome in mice. Proc Natl Acad Sci U S A. 2014;111: 16395-400.

172. Wu X, Simpson J, Hong JH, Kim KH, Thavarajah NK, Backx PH, Neel BG, Araki T. MEK-ERK pathway modulation ameliorates disease phenotypes in a mouse model of Noonan syndrome associated with the Raf1(L613V) mutation. J Clin Invest. 2011;121:1009-25.

173. Araki T, Chan G, Newbigging S, Morikawa L, Bronson RT, Neel BG. Noonan syndrome cardiac defects are caused by PTPN11 acting in endocardium to enhance endocardial-mesenchymal transformation. Proc Natl Acad Sci U S A. 2009;106:4736-41.

174. Liu X, Zheng H, Li X, Wang S, Meyerson HJ, Yang W, Neel BG, Qu CK. Gainof-function mutations of Ptpn11 (Shp2) cause aberrant mitosis and increase susceptibility to DNA damage-induced malignancies. Proc Natl Acad Sci U S A. 2016;113:984-9.

175. Yoshida R, Hasegawa T, Hasegawa Y, Nagai T, Kinoshita E, Tanaka Y, Kanegane H, Ohyama K, Onishi T, Hanew K, et al. Protein-tyrosine phosphatase, nonreceptor type 11 mutation analysis and clinical assessment in 45 patients with Noonan syndrome. J Clin Endocrinol Metab. 2004;89:3359-64.

176. Keilhack H, David FS, McGregor M, Cantley LC, Neel BG. Diverse biochemical properties of Shp2 mutants. Implications for disease phenotypes. J Biol Chem. 2005;280:30984-93.

177. Neel BG, Gu H, Pao L. The 'Shp'ing news: SH2 domain-containing tyrosine phosphatases in cell signaling. Trends Biochem Sci. 2003;28:284-93.

178. Ernst M, Jenkins BJ. Acquiring signalling specificity from the cytokine receptor gp130. Trends Genet. 2004;20:23-32.

179. Feng GS. Shp-2 tyrosine phosphatase: signaling one cell or many. Exp Cell Res. 1999;253:47-54.
180. Chong ZZ, Maiese K. The Src homology 2 domain tyrosine phosphatases SHP-1 and SHP-2: diversified control of cell growth, inflammation, and injury. Histol Histopathol. 2007;22:1251-67.

181. Marin TM, Clemente CF, Santos AM, Picardi PK, Pascoal VD, Lopes-Cendes I, Saad MJ, Franchini KG. Shp2 negatively regulates growth in cardiomyocytes by controlling focal adhesion kinase/Src and mTOR pathways. Circ Res. 2008;103:813-24.

182. Neel BG. Structure and function of $\mathrm{SH} 2$-domain containing tyrosine phosphatases. Semin Cell Biol. 1993;4:419-32.

183. Qu CK. The SHP-2 tyrosine phosphatase: signaling mechanisms and biological functions. Cell Res. 2000;10:279-88.

184. Cai Z, Feng GS, Zhang X. Temporal requirement of the protein tyrosine phosphatase Shp2 in establishing the neuronal fate in early retinal development. J Neurosci. 2010;30:4110-9.

185. Huang YS, Cheng CY, Chueh SH, Hueng DY, Huang YF, Chu CM, Wu ST, Tai MC, Liang CM, Liao MH, et al. Involvement of SHP2 in focal adhesion, migration and differentiation of neural stem cells. Brain and Development. 2012;34:674-84

186. Kuo E, Park DK, Tzvetanova ID, Leiton CV, Cho BS, Colognato H. Tyrosine phosphatases Shp1 and Shp2 have unique and opposing roles in oligodendrocyte development. J Neurochem. 2010;113:200-12.

187. Liu X, Li Y, Zhang Y, Lu Y, Guo W, Liu P, Zhou J, Xiang Z, He C. SHP-2 promotes the maturation of oligodendrocyte precursor cells through Akt and ERK1/2 signaling in vitro. PLoS One. 2011;6:e21058.

188. Grossmann KS, Wende H, Paul FE, Cheret C, Garratt AN, Zurborg S, Feinberg K, Besser D, Schulz H, Peles E, et al. The tyrosine phosphatase Shp2 (PTPN11) directs Neuregulin-1/ErbB signaling throughout Schwann cell development. Proc Natl Acad Sci U S A. 2009;106:16704-9.

189. Anastasaki C, Estep AL, Marais R, Rauen KA, Patton EE. Kinase-activating and kinase-impaired cardio-facio-cutaneous syndrome alleles have activity during zebrafish development and are sensitive to small molecule inhibitors. Hum Mol Genet. 2009:18:2543-54.

190. Yeh E, Dao DQ, Wu ZY, Kandalam SM, Camacho FM, Tom C, Zhang W, Krencik R, Rauen KA, Ullian EM, et al. Patient-derived iPSCs show premature neural differentiation and neuron type-specific phenotypes relevant to neurodevelopment. Mol Psychiatry. 2017;23(8):1687-98.

191. Yeh TH, Lee DY, Gianino SM, Gutmann DH. Microarray analyses reveal regional astrocyte heterogeneity with implications for neurofibromatosis type 1 (NF1)-regulated glial proliferation. Glia. 2009;57:1239-49.

192. Moriya M, Inoue S, Miyagawa-Tomita S, Nakashima Y, Oba D, Niihori T, Hashi M, Ohnishi H, Kure S, Matsubara Y, et al. Adult mice expressing a Braf Q241R mutation on an ICR/CD-1 background exhibit a cardio-facio-cutaneous syndrome phenotype. Hum Mol Genet. 2015;24:7349-60.

193. Wiese S, Pei G, Karch C, Troppmair J, Holtmann B, Rapp UR, Sendtner M. Specific function of B-Raf in mediating survival of embryonic motoneurons and sensory neurons. Nat Neurosci. 2001;4:137-42.

194. Wojnowski L, Zimmer AM, Beck TW, Hahn H, Bernal R, Rapp UR, Zimmer A. Endothelial apoptosis in Braf-deficient mice. Nat Genet. 1997;16:293-7.

195. Chen AP, Ohno M, Giese KP, Kuhn R, Chen RL, Silva AJ. Forebrain-specific knockout of B-raf kinase leads to deficits in hippocampal long-term potentiation, learning, and memory. J Neurosci Res. 2006;83:28-38.

196. Andreadi C, Cheung LK, Giblett S, Patel B, Jin H, Mercer K, Kamata T, Lee P, Williams A, McMahon M, et al. The intermediate-activity (L597V)BRAF mutant acts as an epistatic modifier of oncogenic RAS by enhancing signaling through the RAF/MEK/ERK pathway. Genes Dev. 2012;26:1945-58.

197. Inoue S, Moriya M, Watanabe Y, Miyagawa-Tomita S, Niihori T, Oba D, Ono M, Kure S, Ogura T, Matsubara Y, et al. New BRAF knockin mice provide a pathogenetic mechanism of developmental defects and a therapeutic approach in cardio-facio-cutaneous syndrome. Hum Mol Genet. 2014;23:6553-66.

198. Gripp KW, Hopkins E, Sol-Church K, Stabley DL, Axelrad ME, Doyle D, Dobyns WB, Hudson C, Johnson J, Tenconi R, et al. Phenotypic analysis of individuals with Costello syndrome due to HRAS p.G13C. Am J Med Genet A. 2011;155a:706-16.

199. Abe Y, Aoki Y, Kuriyama S, Kawame H, Okamoto N, Kurosawa K, Ohashi H, Mizuno S, Ogata T, Kure S, et al. Prevalence and clinical features of Costello syndrome and cardio-facio-cutaneous syndrome in Japan: findings from a nationwide epidemiological survey. Am J Med Genet A. 2012;158a:1083-94.

200. Costello JM. A new syndrome: mental subnormality and nasal papillomata. Aust Paediatr J. 1977;13:114-8.

201. Gripp KW, Lin AE, Stabley DL, Nicholson L, Scott CI Jr, Doyle D, Aoki Y, Matsubara Y, Zackai EH, Lapunzina P, et al. HRAS mutation analysis in 
Costello syndrome: genotype and phenotype correlation. Am J Med Genet A. 2006;140:1-7.

202. Gibbs JB, Sigal IS, Poe M, Scolnick EM. Intrinsic GTPase activity distinguishes normal and oncogenic ras p21 molecules. Proc Natl Acad Sci U S A. 1984; 81:5704-8.

203. Bertola DR, Pereira AC, Brasil AS, Albano LM, Kim CA, Krieger JE. Further evidence of genetic heterogeneity in Costello syndrome: involvement of the KRAS gene. J Hum Genet. 2007;52:521-6.

204. Gripp KW, Lin AE. Costello syndrome: a Ras/mitogen activated protein kinase pathway syndrome (rasopathy) resulting from HRAS germline mutations. Genet Med. 2012;14:285-92.

205. Lin AE, Alexander ME, Colan SD, Kerr B, Rauen KA, Noonan J, Baffa J, Hopkins E, Sol-Church K, Limongelli G, et al. Clinical, pathological, and molecular analyses of cardiovascular abnormalities in Costello syndrome: a Ras/MAPK pathway syndrome. Am J Med Genet A. 2011:155a:486-507.

206. Krencik R, Hokanson KC, Narayan AR, Dvornik J, Rooney GE, Rauen KA, Weiss LA, Rowitch DH, Ullian EM. Dysregulation of astrocyte extracellular signaling in Costello syndrome. Sci Transl Med. 2015;7:286ra66.

207. Rooney GE, Goodwin AF, Depeille P, Sharir A, Schofield CM, Yeh E, Roose JP, Klein OD, Rauen KA, Weiss LA, et al. Human iPS Cell-Derived Neurons Uncover the Impact of Increased Ras Signaling in Costello Syndrome. J Neurosci. 2016;36:142-52.

208. Gripp KW, Hopkins E, Doyle D, Dobyns WB. High incidence of progressive postnatal cerebellar enlargement in Costello syndrome: brain overgrowth associated with HRAS mutations as the likely cause of structural brain and spinal cord abnormalities. Am J Med Genet A. 2010;152a:1161-8.

209. Schuhmacher AJ, Guerra C, Sauzeau V, Canamero M, Bustelo XR, Barbacid M. A mouse model for Costello syndrome reveals an Ang II-mediated hypertensive condition. J Clin Invest. 2008;118:2169-79.

210. Viosca J, Schuhmacher AJ, Guerra C, Barco A. Germline expression of HRas(G12V) causes neurological deficits associated to Costello syndrome. Genes Brain Behav. 2009;8:60-71.

211. Paquin A, Hordo C, Kaplan DR, Miller FD. Costello syndrome H-Ras alleles regulate cortical development. Dev Biol. 2009;330:440-51.

212. Daston MM, Ratner N. Neurofibromin, a predominantly neuronal GTPase activating protein in the adult, is ubiquitously expressed during development. Dev Dyn. 1992;195:216-26.

213. Krab LC, de Goede-Bolder A, Aarsen FK, Pluijm SM, Bouman MJ, van der Geest JN, Lequin M, Catsman CE, Arts WF, Kushner SA, et al. Effect of simvastatin on cognitive functioning in children with neurofibromatosis type 1: a randomized controlled trial. Jama. 2008;300:287-94.

214. van der Vaart T, Plasschaert E, Rietman AB, Renard M, Oostenbrink R, Vogels $A$, de Wit MC, Descheemaeker MJ, Vergouwe Y, Catsman-Berrevoets $C E$, et al. Simvastatin for cognitive deficits and behavioural problems in patients with neurofibromatosis type 1 (NF1-SIMCODA): a randomised, placebocontrolled trial. Lancet Neurol. 2013;12:1076-83.

215. Payne JM, Barton B, Ullrich NJ, Cantor A, Hearps SJ, Cutter G, Rosser T, Walsh KS, Gioia GA, Wolters PL, et al. Randomized placebo-controlled study of lovastatin in children with neurofibromatosis type 1. Neurology. 2016;87: 2575-84.

216. Stivaros S, Garg S, Tziraki M, Cai Y, Thomas O, Mellor J, Morris AA, Jim C, Szumanska-Ryt K, Parkes LM, et al. Randomised controlled trial of simvastatin treatment for autism in young children with neurofibromatosis type 1 (SANTA). Molecular autism. 2018;9:12.

217. Omrani A, van der Vaart T, Mientjes E, van Woerden GM, Hojjati MR, Li KW, Gutmann DH, Levelt CN, Smit AB, Silva AJ, et al. HCN channels are a novel therapeutic target for cognitive dysfunction in Neurofibromatosis type 1. Mol Psychiatry. 2015;20:1311-21.

218. Howe JR, Bear MF, Golshani P, Klann E, Lipton SA, Mucke L, Sahin M, Silva AJ. The mouse as a model for neuropsychiatric drug development. Curr Biol. 2018;28:R909-R14.

\section{Publisher's Note}

Springer Nature remains neutral with regard to jurisdictional claims in published maps and institutional affiliations. 